\title{
Transcriptional Changes in Mycorrhizal and Nonmycorrhizal Soybean Plants upon Infection with the Fungal Pathogen Macrophomina phaseolina
}

\author{
Nathalie Marquez,, ${ }^{1,2}$ María L. Giachero, ${ }^{1}$ Adrien Gallou, ${ }^{3}$ Humberto J. Debat, ${ }^{1}$ Sylvie Cranenbrouck, ${ }^{4}$ \\ Julio A. Di Rienzo, ${ }^{5}$ María J. Pozo, ${ }^{6}$ Daniel A. Ducasse, ${ }^{1}$ and Stéphane Declerck ${ }^{7, \dagger}$ \\ ${ }^{1}$ Instituto de Patología Vegetal, Centro de Investigaciones Agropecuarias, Instituto Nacional de Tecnología Agropecuaria, \\ Camino 60 cuadras km 5.5, 5119. Córdoba, Argentina; ${ }^{2}$ Consejo Nacional de Investigaciones Científicas y Técnicas, Argentina; \\ ${ }^{3}$ Centro Nacional de Referencia de Control Biológico, Km 1.5 Carretera Tecomán-Estación FFCC. Apdo. Postal 67, Tecomán, \\ Colima, México; ${ }^{4}$ Université catholique de Louvain, Earth and Life Institute, Applied Microbiology, Mycology, Mycothèque de \\ I'Université catholique de Louvain (MUCL), Part of the Belgian Coordinated Collections of Microorganisms (BCCM), Croix du \\ Sud 2, bte L7.05.06, B-1358, Louvain-la-Neuve, Belgium; ${ }^{5}$ Cátedra de Estadística y Biometría, Facultad de Ciencias \\ Agropecuarias, Universidad Nacional de Córdoba, Ing Agr; Felix Aldo Marrone 746, 5000 Córdoba, Argentina; ${ }^{6}$ Department of \\ Soil Microbiology and Symbiotic Systems, Estación Experimental del Zaidín, CSIC, Prof. Albareda 1, 18008, Granada, Spain; \\ ${ }^{7}$ Université catholique de Louvain, Earth and Life Institute, Applied Microbiology, Mycology, Croix du Sud 2, bte L7.05.06, \\ B-1358, Louvain-la-Neuve, Belgium
}

Accepted 28 February 2018.

\begin{abstract}
Macrophomina phaseolina is a soil-borne fungal pathogen with a wide host range that causes charcoal rot in soybean [Glycine $\max (\mathrm{L}$.) Merr.]. Control of the disease is a challenge, due to the absence of genetic resistance and effective chemical control. Alternative or complementary measures are needed, such as the use of biological control agents, in an integrated approach. Several studies have demonstrated the role of arbuscular mycorrhizal fungi (AMF) in enhancing plant resistance or tolerance to biotic stresses, decreasing the symptoms and pressure caused by various pests and diseases, including $M$. phaseolina in soybean. However, the specific contribution of AMF in the regulation of the plant response to $M$. phaseolina remains unclear. Therefore, the objective of the present study was to investigate, under strict in-vitro culture conditions, the global transcriptional changes in roots of premycorrhized soybean plantlets challenged by $M$. phaseolina (+AMF+Mp) as compared with nonmycorrhizal soybean plantlets $(-\mathbf{A M F}+\mathbf{M p})$. MapMan software was used to distinguish transcriptional changes, with special emphasis on those related to plant defense responses. Soybean genes identified as strongly upregulated during infection by the pathogen included pathogenesis-related proteins, disease-resistance proteins, transcription factors, and secondary metabolism-related genes, as well as those encoding for signaling hormones. Remarkably, the $+\mathrm{AMF}+\mathrm{Mp}$ treatment
\end{abstract}

Funding: N. Marquez is CONICET fellow and thanks ANPCyT and BEC. AR program, Argentina.

The microarray data have been deposited in the National Center for Biotechnology Information Gene Expression Omnibus database and are accessible through GEO series accession number GSE87740.

${ }^{\dagger}$ Corresponding author: Stéphane Declerck;

E-mail: stephan.declerck@uclouvain.be

*The $\boldsymbol{e}$-Xtra logo stands for "electronic extra" and indicates that four supplementary figures and three supplementary tables are published online.

(c) 2018 The American Phytopathological Society displayed a lower number of upregulated genes as compared with the $-\mathrm{AMF}+\mathrm{Mp}$ treatment. AMF seemed to counteract or balance costs upon M. phaseolina infection, which could be associated to a negative impact on biomass and seed production. These detailed insights in soybean-AMF interaction help us to understand the complex underlying mechanisms involved in AMF-mediated biocontrol and support the importance of preserving and stimulating the existing plant-AMF associates, via adequate agricultural practices, to optimize their agro-ecological potential.

Soybean is one of the most important crops worldwide, covering $6 \%$ of the arable land (Hartman et al. 2011). The United States, Brazil, and Argentina are the world leading soybean-producing countries (FAOstat website). In Argentina, soybean production increased very rapidly in the last 20 years compared with other crops. It is, nowadays, the major extensive crop, which is estimated to cover 20 million hectares with an annual production of 53 million tons (Bolsa de Comercio de Rosario website).

The Compendium of Soybean Diseases lists over 100 diseases of soybean (Hartman et al. 1999), of which 30 have been reported in Argentina (Giorda and Baigorri 1997; Wrather et al. 2010). The number and severity of infectious diseases has increased steadily, particularly since the early 1990s (Ploper 2004). Among these, charcoal rot of soybean is one of the most severe. In fact, it was the most prevalent disease affecting roots and lower stems in the 2005-2006 soybean-growing season in several Argentinean provinces (Wrather et al. 2010).

Charcoal rot is caused by Macrophomina phaseolina, a generalist soil-borne fungus affecting about 500 plant species in more than 100 families, including many economically important crops such as corn, sunflower, sorghum, chickpea, and potato (Kishore Babu et al. 2007). This broad host range is probably a result of the great number of pathogenicityassociated genes present in the $M$. phaseolina genome, as those encoding for cell wall-degrading enzymes (Islam et al. 2012; Ramos et al. 2016). Initial infection of soybean occurs at the seedling stage. Once in the roots, the fungus moves into the 
cortical tissues, first intercellularly and then intracellularly, finally invading the vascular system. The infected seedlings generally continue their development without visible symptoms of the disease. Nevertheless, under favorable conditions, such as high temperatures (above $30^{\circ} \mathrm{C}$ ) and low soil moisture, charcoal rot disease symptoms usually appear (Arora and Pareek 2013; Kendig et al. 2000; Manici et al. 1995; Mayek-Pérez et al. 2002). Typical symptoms are yellowing and death of the leaves that remain attached to the stems by the petioles, sloughing of cortical tissues from the lower stem and taproot, and the speckled gray appearance of these infected tissues due to abundant microsclerotia formation in vascular, cortical, and pith tissues (Backman and Sinclair 1989; Short et al. 1978; Smith and Carvil 1997; Wyllie 1988). Yield and seed quality are reduced under these conditions and represent a challenge for soybean export (Gupta et al. 2012).

Management of the disease remains challenging, due to the absence of genetic resistance and effective chemical control (Mengistu et al. 2013; Radwan et al. 2014). Crop rotation has not been effective in controlling the disease because of the wide host range and high persistence of $M$. phaseolina in soil as microsclerotia, while irrigation has limited effects in the control of the disease (Kendig et al. 2000).

Soil contains a tremendous diversity and abundance of microbes, with millions of species or ecotypes (Declerck et al. 2015). Many of these soil microbes inhabit the rhizosphere and are beneficial to plants, improving their nutrition, producing plant growth-promoting metabolites, or providing protection against root pathogens (Raaijmakers et al. 2009). Among the beneficial microorganisms are the arbuscular mycorrhizal fungi (AMF). These soil fungi and their hosts probably represent the oldest and most widespread plant-microbe mutualistic interaction on earth (Smith and Carvil 1997). They have been reported to improve either growth, yield, or both of plants via a better nutritional status (Cely et al. 2016). It is well-known that AMF brings significant changes in the host plant and its environment and can reduce the incidence or severity of diseases caused by diverse soil-borne pathogens (Campos-Soriano et al. 2012; Karthikeyan et al. 2016; Nadeem et al. 2014; Pozo et al. 2010). Reduction in $M$. phaseolina colonization or disease symptoms severity in mycorrhized plants was earlier reported in various pathosystems, including soybean plants (Doley et al. 2014; Spagnoletti et al. 2017). Furthermore, reduction in plant growth that could have resulted from $M$. phaseolina infestation was reverted by AMF inoculation, recovering a normal growth (Oyewole et al. 2017). Thus, AMF have been suggested as effective agents in the biological management of diseases (Dar and Reshi 2017; Gianinazzi et al. 2010).

Mycorrhiza-induced protection has been attributed to several mechanisms that may operate simultaneously (Cameron et al. 2013; Pozo and Azcón Aguilar 2007). For example, AMF can compete with soil-borne pathogens for space and nutrients and may even alter root morphology, changing the dynamics of pathogen infection. AMF colonization can also lead to alterations in the quality and quantity of root exudates impacting the microbial community of the rhizosphere (Azcón-Aguilar and Barea 1997; Pivato et al. 2008). Recent findings indicate that the primary mechanism of plant protection against pathogens occurs through the ability of AMF to reprogram plant gene expression and metabolism, particularly in relation to defense (Campos-Soriano et al. 2012; Gallou et al. 2012; Güimil et al. 2005; Liu et al. 2003, 2007; López-Ráez et al. 2010; Rivero et al. 2015; Sanchez-Bel et al. 2016). AMF modulation may also result in preconditioning of the tissues for efficient activation of plant defenses upon a challenger attack, a phenomenon that is called priming (Pozo and Azcón-Aguilar 2007). Fitness costs of priming are substantially lower than those of the direct induced defense against pathogens (Conrath et al. 2015; Martinez-Medina et al. 2016; Mauch-Mani et al. 2017).

Most of the defense mechanisms associated with AMF have been reported in pot systems, under conditions that could not prevent the presence of unwanted microbes, thus potentially leading to confounding effects (Cameron et al. 2013). Moreover, pot systems make it difficult to observe and follow nondestructively the different steps leading to root colonization. In-vitro cultivation systems have been proven to be suitable for studying underground interactions and initial infection events (Giachero et al. 2017) as well as gene expression dynamics, since there is no interference with other microbes or environmental factors (Bressano et al. 2010; Fortin et al. 2002; Gallou et al. 2010) and time-lapse infection can be monitored nondestructively by microscopy. For instance, Gallou et al. (2011) used in-vitro cultures to investigate the impact of AMF on defense gene expression in AMF-colonized potato plantlets challenged with Phytophthora infestans. They noticed a systemic resistance in mycorrhizal potato plants, associated to the priming of two pathogenesis-related (PR) protein-coding genes. Likewise, the in-vitro culture system allowed the observation of differences in behavior of $M$. phaseolina in the vicinity of roots and during infection of roots of resistant vs. susceptible varieties of sesame (Chowdhury et al. 2014).

Integrated biological management (IBM) of M. phaseolina has become a necessity, due to its persistence in soils. AMF represent a potential biocontrol agent in IBM programs for disease control (Azcón-Aguilar and Barea 1997; Hooker et al. 1994; Singh et al. 2013; Sui et al. 2014). Even though it has been clearly shown that incidence of disease caused by $M$. phaseolina was significantly decreased in mycorrhizal soybean plants (Spagnoletti et al. 2017), there is a need for deeper studies under highly controlled conditions to understand molecular interactions between this soil-borne pathogen and AMF-colonized plants. Therefore, the objective of the present study was to investigate, under strict in-vitro culture conditions, the global transcriptional change in the roots of premycorrhized soybean plantlets challenged by M. phaseolina as compared with nonmycorrhizal soybean plantlets. MapMan software was used to distinguish transcriptional changes, with special emphasis on those involved in plant defense responses.

\section{RESULTS}

\section{Root colonization by Rhizophagus irregularis.}

At the end of the experiment (day 17, i.e., $72 \mathrm{~h}$ postinoculation [hpi] with $M$. phaseolina), plantlets were harvested and AMF root colonization (RC) was assessed (Supplementary Fig. S1). The percent RC was $36.2 \pm 12.8$ and $30.3 \pm 7.1$ in the $+\mathrm{AMF}-\mathrm{Mp}$ and $+\mathrm{AMF}+\mathrm{Mp}$ treatments, respectively. The percentage of arbuscules was $18.6 \pm 10.5$ and $14.3 \pm 4.9$ in the $+\mathrm{AMF}-\mathrm{Mp}$ and $+\mathrm{AMF}+\mathrm{Mp}$ treatments, respectively. The percentage of spores or vesicles was $2.6 \pm 2.3$ and $3.9 \pm 2.7$ in the $+\mathrm{AMF}-\mathrm{Mp}$ and $+\mathrm{AMF}+\mathrm{Mp}$ treatments, respectively. None of these parameters significantly differed between the two treatments according to the DGC (Di Rienzo, Guzmán, and Casanoves) test (Di Rienzo et al. 2002) $(P \leq 0.05)$.

\section{Root infection by $M$. phaseolina.}

M. phaseolina biomass was detected by quantitative reverse transcription-polymerase chain reaction (qRT-PCR) in roots of the plants from the mycorrhizal $(+\mathrm{AMF}+\mathrm{Mp})$ and nonmycorrhizal (-AMF+Mp) treatments (Supplementary Fig. S2). In both treatments, the pathogen biomass increased significantly between 24 and 72 hpi. There was no significant difference between treatments during this time course according to the DGC test $(P<0.05)$. 
M. phaseolina profusely developed under in-vitro culture conditions. Root symptoms appeared 24 hpi with the pathogen. Brown spots to large browning surfaces turning black were observed on the roots of either the mycorrhizal and nonmycorrhizal plantlets close to the inoculation points of the pathogen. However, browning intensity was higher in $-\mathrm{AMF}+\mathrm{Mp}$ treatment at $72 \mathrm{hpi}$ (Fig. 1). This observation was comparable in the experiments conducted for microarray and $\mathrm{qPCR}$ validation assays.

\section{Differential expression of genes.}

Microarray experiments were performed to profile gene expression in premycorrhized soybean plantlets inoculated $(+\mathrm{AMF}+\mathrm{Mp})$ or not $(+\mathrm{AMF}-\mathrm{Mp})$ with $M$. phaseolina and nonmycorrhizal soybean plantlets inoculated $(-\mathrm{AMF}+\mathrm{Mp})$ or not (-AMF-Mp) with M. phaseolina, $72 \mathrm{hpi}$. Differentially expressed genes were identified in the roots of the plantlets of the +AMF-Mp, $-\mathrm{AMF}+\mathrm{Mp}$, and +AMF+Mp treatments as compared with the $-\mathrm{AMF}-\mathrm{Mp}$ treatment. For simplicity, we used the term 'gene' for a probe set representing a given transcript.

The total number of differentially expressed genes in the three treatments was shown in a Venn diagram (Fig. 2). The roots of the plantlets in the $+\mathrm{AMF}-\mathrm{Mp}$ treatment showed 152 upregulated and 23 downregulated genes compared with control plants $(-\mathrm{AMF}-\mathrm{Mp})$. Major transcriptional changes were noticed in the roots of the $-\mathrm{AMF}+\mathrm{Mp}$ treatment with 776 and 117 genes up- and downregulated, respectively. Meanwhile the roots of the plantlets in the $+\mathrm{AMF}+\mathrm{Mp}$ treatment showed 512 upregulated and 152 downregulated genes. As shown in the Venn diagram (Fig. 2), 373 genes were coregulated in the roots of the plantlets from the $-\mathrm{AMF}+\mathrm{Mp}$ and $+\mathrm{AMF}+\mathrm{Mp}$ treatments, among which 348 were up-regulated and 26 were down-regulated. Furthermore, the roots of the plantlets in the $+\mathrm{AMF}-\mathrm{MP}$ treatment had 86 and 38 coregulated genes with the roots of the plantlets in the $+\mathrm{AMF}+\mathrm{Mp}$ and $-\mathrm{AMF}+\mathrm{Mp}$, respectively. Under the three treatments $(-\mathrm{AMF}+\mathrm{Mp},+\mathrm{AMF}+\mathrm{Mp}$, and +AMF-Mp), 29 genes were coregulated. Finally, 233 genes were differentially expressed solely in the roots of $+\mathrm{AMF}+\mathrm{Mp}$ treatment, of which 116 were up-regulated and 117 were downregulated.

\section{Functional assessment of differentially expressed genes.}

MapMan was used to assign the differentially expressed genes into the different metabolic pathways (Fig. 3). Results revealed that $40.8 \%, 37.7 \%$ and $45.6 \%$ of the differentially expressed genes had an unknown function or could not be

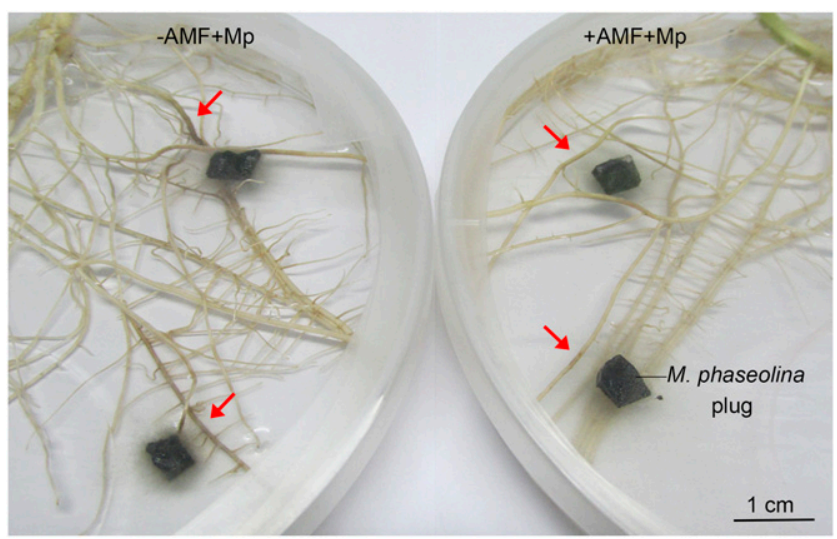

Fig. 1. Necrosis initiation in roots of premycorrhized $(+\mathrm{AMF}+\mathrm{Mp})$ or nonmycorrhized (-AMF+Mp) soybean plantlets $72 \mathrm{~h}$ postinoculation with Macrophomina phaseolina under in-vitro conditions. Red arrows indicate necrosis symptoms. assigned to a specific function in the $+\mathrm{AMF}-\mathrm{Mp},-\mathrm{AMF}+\mathrm{Mp}$, $+\mathrm{AMF}+\mathrm{Mp}$ treatments, respectively. The global transcriptional profiling in premycorrhized soybean plantlets showed major changes in functions related to proteins, secondary metabolism, transport, and hormones.

After root inoculation with $M$. phaseolina, an important transcriptional reprogramming was detected in mycorrhizal and nonmycorrizal plantlets. A strong upregulation of genes involved in secondary metabolism, hormone metabolism, stress, and signaling was detected. However, in the roots of the $+\mathrm{AMF}+\mathrm{Mp}$ treatment, the number of genes within each functional assignment was significantly lower compared with those in the $-\mathrm{AMF}+\mathrm{Mp}$ treatment (Fig. 2).

In general, the number of downregulated genes was lower than the upregulated ones. The $+\mathrm{AMF}+\mathrm{Mp}$ presented more downregulated genes than the $-\mathrm{AMF}+\mathrm{Mp}$ treatment. Most of these genes had homology with the categories miscellanea, transport, proteins, cell wall, and RNA. The roots in the $+\mathrm{AMF}+\mathrm{Mp}$ treatment presented major repression of cell wall-related genes as compared with the two other treatments.

\section{Differentially expressed genes in mycorrhizal roots.}

Mycorrhizal colonization led to several transcriptional changes in soybean roots. One of the most relevant changes was related to protein regulation. Most of these genes encode for two different types of proteases. Serine proteases were strongly up-regulated while cysteine proteases were down-regulated. Additionally, an upregulation of genes involved in development was observed, including genes related to gibberellin (GA) signaling (as those coding for Scarecrow-like 3 [SCL3] protein, which functions as a positive regulator of GA signaling and a GAoxidase) and in auxin regulation (indole 3-acetic acid-amido synthase).

Several secondary metabolism-related genes were up-regulated, more precisely those involved in the phenylpropanoids pathway, like cytochrome P450, 71D8, and 4-coumarate-CoA ligase-like 5. These genes are involved in lignin and flavonoids metabolism. The results also showed an important transcriptional regulation of biotic stress and signaling in mycorrhizal roots. There was an upregulation of genes encoding pathogen-related proteins (PR1 and PR5), dirigent-like protein (DIR) (disease resistanceresponsive), plant basic secretory protein (BSP), protein $\mathrm{P} 21$, lectin precursors (soybean agglutinins), and leucine-rich repeat receptor-like protein (Supplementary Table S1; Supplementary Fig. S3).
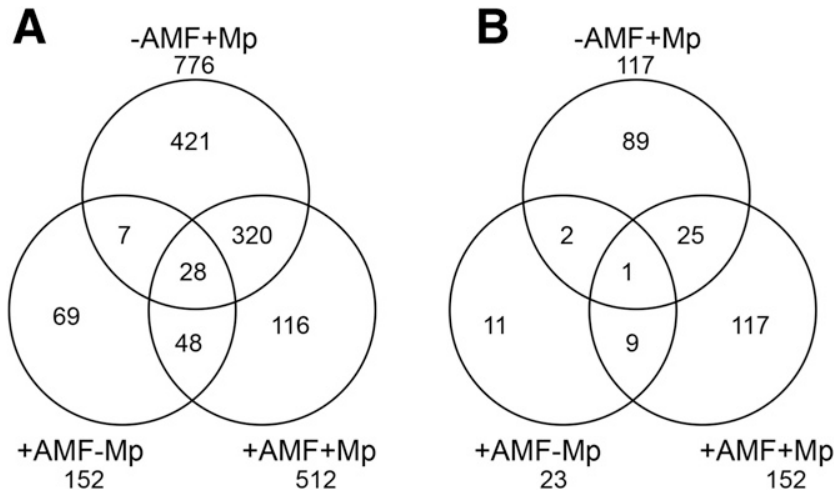

Fig. 2. Venn diagrams showing the relationships between genes significantly $\mathbf{A}$, upregulated and $\mathbf{B}$, downregulated in roots of premycorrhized plantlets inoculated with Macrophomina phaseolina $(+\mathrm{AMF}+\mathrm{Mp})$ or not $(+\mathrm{AMF}-\mathrm{Mp})$ and in roots of nonmycorrhized plantlets inoculated with M. phaseolina $(-\mathrm{AMF}+\mathrm{Mp})$. Genes were considered as differentially regulated if $P \leq 0.005$ and the values of fold change compared with the $-\mathrm{AMF}-\mathrm{Mp}$ treatment was $\geq 3.0$ or $\leq 3$. 


\section{M. phaseolina induced transcriptional regulation in mycorrhizal and nonmycorrhizal roots.}

Among the genes differentially regulated by pathogen infection, the MapMan biotic stress graph (Fig. 4) revealed the upregulation of numerous plant defense genes. Some of them were those related to signaling hormones (auxins, abscisic acid, ethylene, jasmonic acid, and salicylic acid [SA]), PR proteins (PR5-thaumatin-like protein), CAP (cysteine-rich secretory proteins, antigen 5, and PR1 proteins), BSP, DIR, disease-resistance proteins (coiled coil-nucleotide binding site-leucine rich repeat class), endochitinases precursors, polygalacturonase-inhibiting proteins, endo-1,3- $\beta$-glucosidase, ubiquitin, and transcription factors (WRKY, ERF). Moreover, secondary metabolism-related genes were overexpressed as UDP-glucosyltransferase, cytochrome P450, chalcone synthase (CHS), ferulate 5-hydroxylase $(F 5 H)$, and phenylalanine ammonia lyase 1 (PALI). These last five genes are specifically involved in the phenylpropanoid pathway, where plant defense-related compounds arise, like lignin and flavonoids biosynthesis.

Remarkably, transcriptional changes after M. phaseolina inoculation were less pronounced in the roots of mycorrhizal plants $(+\mathrm{AMF}+\mathrm{Mp})$. For instance, the number of induced genes was consistently lower in the $+\mathrm{AMF}+\mathrm{Mp}$ than $-\mathrm{AMF}+\mathrm{Mp}$ treatment, while, conversely, the amount of repressed genes was higher in the $+\mathrm{AMF}+\mathrm{Mp}$ treatment.

A few genes were down-regulated in plantlets inoculated with $M$. phaseolina. These genes had high homology with cysteine proteases and cell wall-associated genes encoding xyloglucan endo-transglycosylase, brassinosteroid-regulated protein BRU1 precursor. However, in addition to the cell wall-related genes mentioned above, $+\mathrm{AMF}+\mathrm{Mp}$ treatment also showed a noticeable repression of genes encoding fasciclin-like

DNA

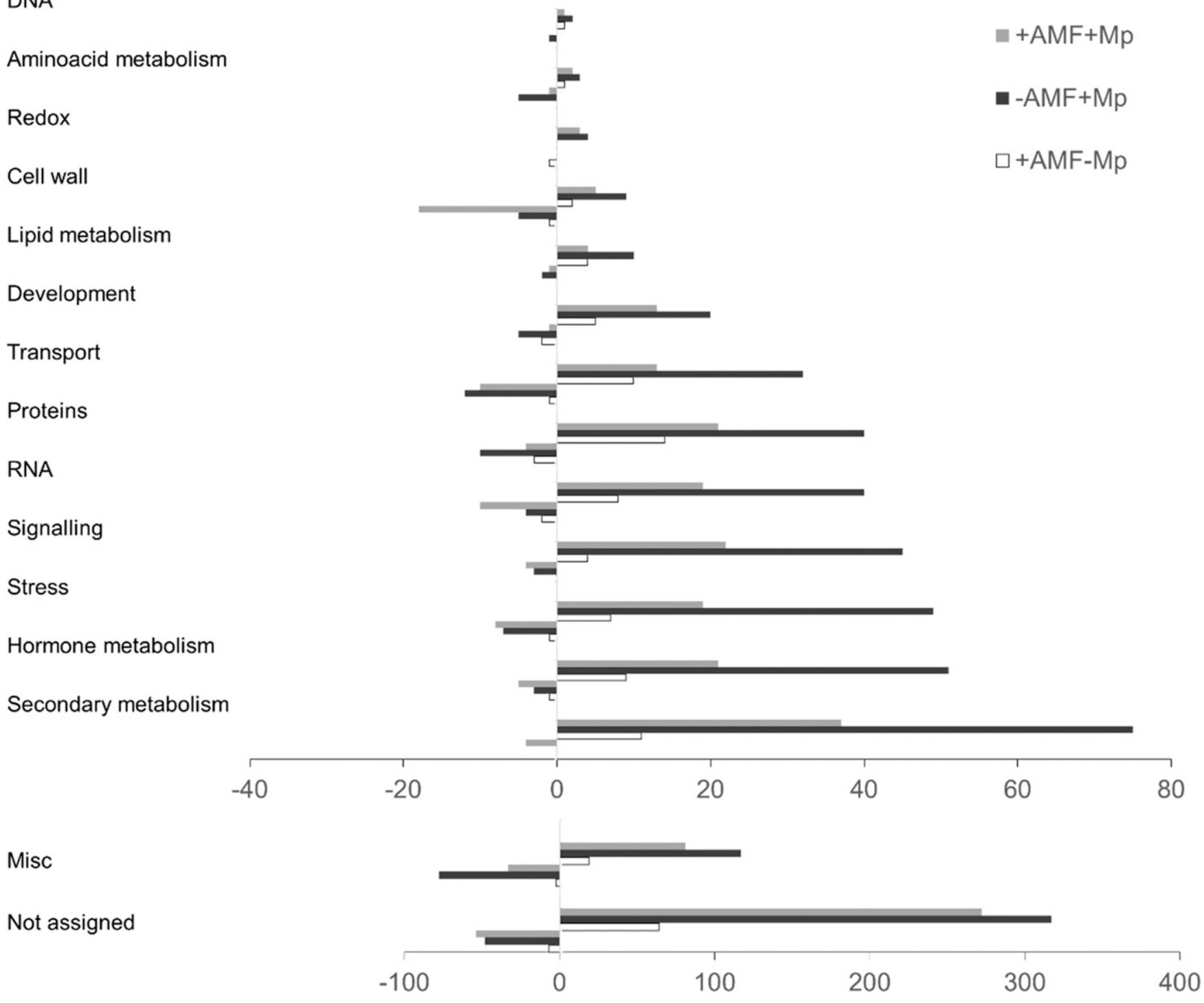

\section{Number of genes in each functional assignment}

Fig. 3. Comparative analysis of transcription profiles. Functional assignment determined by MapMan software of genes significantly upregulated (right of the $y$ axis) or downregulated (left of the $y$ axis) in roots of premycorrhized plantlets inoculated (+AMF+Mp) or not (+AMF-Mp) with Macrophomina phaseolina and in roots of nonmycorrhized plantlets inoculated with M. phaseolina $(-\mathrm{AMF}+\mathrm{Mp})$. Genes were considered as differentially regulated if $P \leq 0.005$ and the values of fold change compared with the $-\mathrm{AMF}-\mathrm{Mp}$ treatment was $\geq 3.0$ or $\leq 3$. 

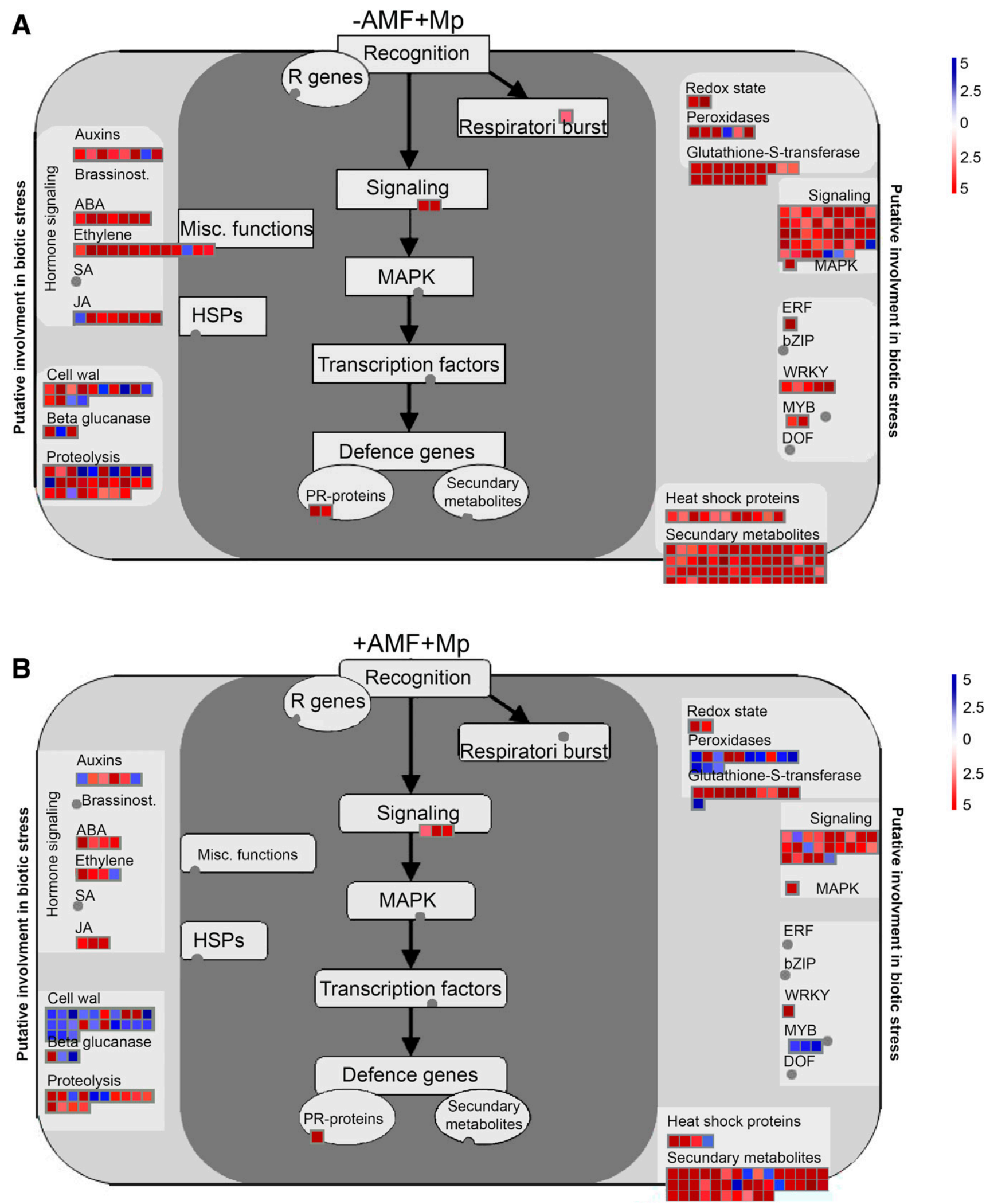

Fig. 4. Impact of arbuscular mycorrhizal fungi (AMF) precolonization of soybean plantlets and Macrophomina phaseolina inoculation on gene expression in soybean roots. A, MapMan biotic stress graph generated using the 893 distinctively regulated genes identified in roots after $72 \mathrm{~h}$ postinoculation (hpi) with Macrophomina phaseolina versus the nonmycorrhized soybean plantlets not inoculated with M. phaseolina. B, MapMan biotic stress graph generated using the 664 genes distinctively regulated identified in roots of AMF-colonized plantlets after $72 \mathrm{hpi}$ with $M$. phaseolina versus the nonmycorrhized soybean plantlets not inoculated with M. phaseolina. The fold change is displayed as illustrated in the color bar of the panel (blue is downregulated and red is upregulated). Genes were considered as differentially regulated if $P \leq 0.005$ and the values of fold change compared with the -AMF-Mp treatment was $\geq 3.0$ or $\leq 3$. 
arabinogalactan-protein and SKU5 similar 5 and biotic stressrelated genes encoding an endo-chitinase, MYB transcription factors, and peroxidases.

Furthermore, fold change (FC) values comparison of coregulated genes between $+\mathrm{AMF}+\mathrm{Mp}$ and $-\mathrm{AMF}+\mathrm{Mp}$ treatments, showed that most of the upregulated genes in premycorrhized plantlets had lower FC values than nonmycorrhized plantlets after M. phaseolina inoculation (Supplementary Table S2).

Despite this, a set of genes showed primed expression in mycorrhizal roots upon $M$. phaseolina infection, as they were induced exclusively or to a higher level in mycorrhizal roots (Table 1). Strikingly, the genes with primed expression upon pathogen infection in mycorrhizal plants are, in their majority, uncharacterized, without function assignments. While the proportion of differentially expressed genes with unknown function according to the MapMan analysis was about $40 \%$ in the roots of $+\mathrm{AMF}-\mathrm{Mp},-\mathrm{AMF}+\mathrm{Mp},+\mathrm{AMF}+\mathrm{Mp}$ treatments, it increases to over $80 \%$ in the group of genes with primed expression in mycorrhizal roots $(+\mathrm{AMF}+\mathrm{Mp}$ as compared with $-\mathrm{AMP}+\mathrm{Mp}$ ) and, accordingly, could not be analyzed with the MapMan software. Noteworthy, the small proportion of mycorrhiza-primed genes with assigned functions are related to regulation of transcription or postranscriptional modifications (protein modification, protein degradation) and receptor kinases (Supplementary Fig. S4). Glutathione $S$ transferase
(GST) genes were induced by the pathogen with primed expression in mycorrhizal plants. Moreover, there were downregulated genes, encoding, for example, a putative extensin protein and a proline-rich protein, whose repression upon M. phaseolina infection was more pronounced in $+\mathrm{AMF}+\mathrm{Mp}$ treatment.

qPCR validation of gene expression.

To validate the microarray data and their biological significance, we selected some genes with differential regulation patterns and analyzed their expression levels by real-time qPCR. Target genes were assessed at different timepoints after pathogen infection in a new experiment, which allowed us to explore the dynamics of the regulation upon pathogen infection. We selected markers from the different transcriptional profiles found through the microarray analysis; one gene upregulated by mycorrhiza regardless of the presence or absence of the pathogen, coding for a lectin precursor. PAL1 was selected as a pathogen-induced gene with higher expression in nonmycorrhizal plantlets, and the gene encoding a DIR was selected as a pathogen-induced gene with primed expression in mycorrhizal plants. Finally, we included other genes of relevance in root defense responses, such as those encoding the phenylpropanoid-related enzyme CHS and PR1. Gene expression data were analyzed using three-way analysis of variance.

Table 1. Up- and downregulated genes with primed expression in premycorrhized (+AMF+Mp) soybean roots at $72 \mathrm{~h}$ postinoculation with Macrophomina phaseolina compared with nonmycorrhized treatment $(-\mathrm{AMF}+\mathrm{Mp})^{\mathrm{a}}$

\begin{tabular}{|c|c|c|c|c|c|}
\hline \multirow[b]{2}{*}{ Bin code } & \multirow[b]{2}{*}{ Bin name } & \multirow[b]{2}{*}{ ID no. } & \multirow[b]{2}{*}{ MapMan description } & \multicolumn{2}{|c|}{ Fold change } \\
\hline & & & & $-\mathbf{A M F}+\mathbf{M p}$ & $+\mathrm{AMF}+\mathrm{Mp}$ \\
\hline 16.8.3.3 & Secondary metabolism & BW667916.1 & Cytochrome P450 93A1 & 31.2 & 68.8 \\
\hline 20.1 & Stress & BU549825.1 & $\begin{array}{l}\text { Disease resistance-responsive (dirigent-like protein) } \\
\text { family protein }\end{array}$ & 50.8 & 185.0 \\
\hline 24.2 & Biodegradation of xenobiotics & BE658903.1 & Lactoylglutathione lyase/glyoxalase I family protein & 9.3 & 16.4 \\
\hline 26.1 & Miscellaneous & AW349500.1 & Aldolase-type TIM barrel family protein & 29.3 & 40.0 \\
\hline 26.10 & Miscellaneous & BU926443.1 & Cytochrome P450 82A2 & 35.0 & 41.8 \\
\hline 26.10 & Miscellaneous & BU578331.1 & Cytochrome P450 93A1 & 23.3 & 35.4 \\
\hline 26.10 & Miscellaneous & BQ079433.1 & Cytochrome p450 family & 27.1 & 52.6 \\
\hline 26.10 & Miscellaneous & BU547972.1 & Cytochrome P450 71D8 & 100.4 & 128.3 \\
\hline 26.10 & Miscellaneous & CX710116.1 & Cytochrome P450 82A2 & 68.3 & 103.0 \\
\hline 26.10 & Miscellaneous & CF807834.1 & Cytochrome P450 Member of CYP81D & 28.4 & 79.4 \\
\hline 26.21 & Miscellaneous & CA850987.1 & $14-\mathrm{kDa}$ proline-rich protein DC2.15 precursor & -3.4 & -9.2 \\
\hline 26.24 & Miscellaneous & BU579058.1 & Acyl-CoA $N$-acyltransferases (NAT) superfamily protein & 25.1 & 70.6 \\
\hline 26.9 & Miscellaneous & BU762267.1 & Probable glutathione $S$-transferase (GST) & 18.5 & 39.3 \\
\hline 26.9 & Miscellaneous & BI971101.1 & $\begin{array}{l}\text { Encodes glutathione transferase belonging to the tau } \\
\text { class of GSTs }\end{array}$ & 22.2 & 114.2 \\
\hline 26.9 & Miscellaneous & BW666684.1 & Probable GST & 70.9 & 305.7 \\
\hline 26.9 & Miscellaneous & BW677943.1 & $\begin{array}{l}\text { Encodes glutathione transferase belonging to the tau } \\
\text { class of GSTs }\end{array}$ & 64.9 & 314.8 \\
\hline 27.3 .11 & RNA & CX712124.1 & $\mathrm{C} 2 \mathrm{H} 2$-type zinc finger family protein & 15.5 & 28.6 \\
\hline 29.2.1.2.2.10 & Protein & CX709006.1 & $60 S$ ribosomal protein L10 (EQM) & 104.2 & 341.0 \\
\hline 29.4 & Protein & BU550168.1 & Protein kinase; AGC2-1 & 48.5 & 54.7 \\
\hline 29.5.3 & Protein & BW673849.1 & Cysteine proteinase inhibitor (Cystatin) & 9.7 & 14.9 \\
\hline 30.3 & Signaling & BW655240.1 & AtCP1 encodes a novel $\mathrm{Ca} 2+-$ binding protein & 12.7 & 21.6 \\
\hline 33.99 & Development & CX702141.1 & Nodulin MtN3 family protein & 8.5 & 13.6 \\
\hline 35.1 & Not assigned & BU550330.1 & SOUL-1 & 41.0 & 73.1 \\
\hline 35.2 & Not assigned & BW670549.1 & No hits & -3.9 & -10.7 \\
\hline 35.2 & Not assigned & BW669369.1 & No hits & 15.5 & 20.9 \\
\hline 35.2 & Not assigned & CA850553.1 & No hits & 60.0 & 68.3 \\
\hline 35.2 & Not assigned & BE820990.1 & No hits & 34.2 & 47.4 \\
\hline 35.2 & Not assigned & BE820233.1 & No hits & 27.7 & 46.5 \\
\hline 35.2 & Not assigned & BW680503.1 & No hits & 28.0 & 47.6 \\
\hline 35.2 & Not assigned & CF808638.1 & No hits & 27.6 & 55.7 \\
\hline 35.2 & Not assigned & CD396219.1 & No hits & 29.3 & 58.0 \\
\hline 35.2 & Not assigned & BQ612411.1 & No hits & 24.4 & 56.4 \\
\hline 35.2 & Not assigned & CF808725.1 & Stress-induced protein SAM22 & 52.6 & 100.7 \\
\hline 35.2 & Not assigned & BW655785.1 & No hits & 22.3 & 80.7 \\
\hline 35.2 & Not assigned & CF808824.1 & No hits & 86.1 & 173.0 \\
\hline
\end{tabular}

${ }^{a}$ Data are organized by bin code. 


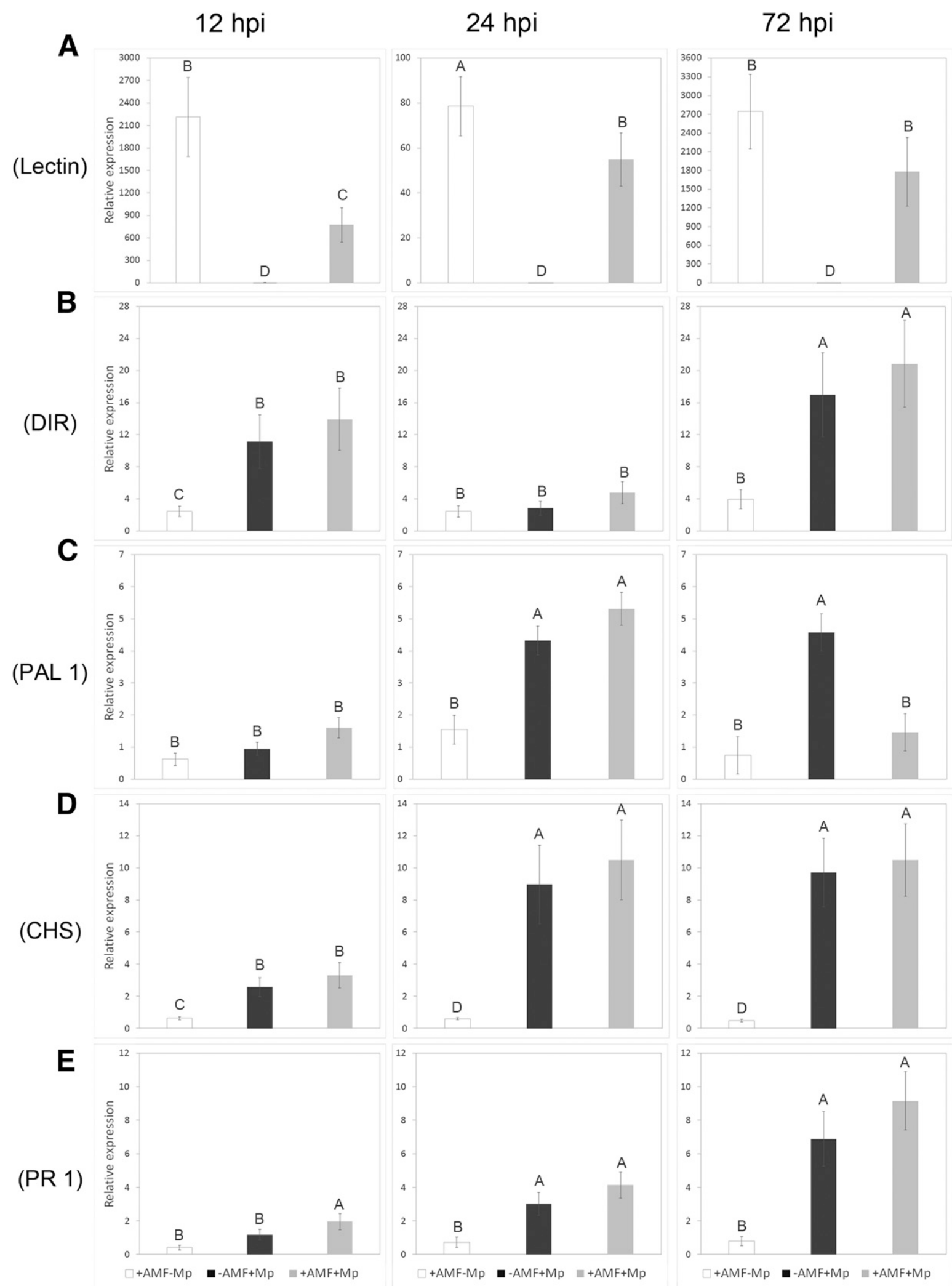

Fig. 5. Transcript levels of defense-related genes in roots of premycorrhized plantlets inoculated with Macrophomina phaseolina (+AMF+Mp) or not $(+\mathrm{AMF}-\mathrm{Mp})$ and in roots of nonmycorrhized plantlets inoculated with M. phaseolina (-AMF +Mp) or not (-AMF-Mp). Quantitative reverse transcriptionpolymerase chain reaction was employed to detect the transcripts of five defense-related genes encoding $\mathbf{A}$, lectin precursors (soybean agglutinins), B, dirigentlike protein (DIR), C, phenylalanine ammonia-lyase 1 (PAL1), D, chalcone synthase (CHS), and E, pathogen-related proteins (PR1). Data are means of four biological replicates $(n=4)$. Error bars represent standard error. Transcript levels are expressed relative to the nonmycorrhized soybean plantlets noninoculated with M. phaseolina (-AMF-Mp). Different letters indicate significant differences at $P \leq 0.05$ (DGC comparison method). 
Interaction between AMF, pathogen, and time (hpi) was significant $(P \leq 0,05)$ solely for PAL1. Nevertheless, for the other analyzed genes, comparison of all the mean involved in the interaction were assessed.

The results (Fig. 5) confirmed the AMF-related regulation of the lectin gene, as it was highly expressed in mycorrhizal roots, regardless of the presence of the pathogen (+AMF-Mp, +AMF+Mp). In the case of PAL1, the qPCR results confirmed that the gene was significantly induced by the pathogen and the expression was higher in $-\mathrm{AMF}+\mathrm{Mp}$ than in $+\mathrm{AMF}+\mathrm{Mp}$ at $72 \mathrm{hpi}$, as revealed by the microarray analysis in the previous experiment. However, expression levels were similar among both treatments in earlier timepoints. Regarding DIR expression levels, gene transcripts were also increased after $M$. phaseolina inoculation in both mycorrhizal and nonmycorrhizal plants (-AMF+Mp and +AMF+Mp treatments). Unfortunately, although in the three postinoculation times analyzed, the expression levels in $+\mathrm{AMF}+\mathrm{Mp}$ treatment was higher than in $-\mathrm{AMF}+\mathrm{Mp}$, the increase was not statistically significant, as in the first experiment. We observed a similar result with GST 10 and GST 12 genes. These genes showed primed induction in the $+\mathrm{AMF}+\mathrm{Mp}$ treatment at $72 \mathrm{hpi}$ in the microarray experiment, while no significant differences were observed during the time course by qPCR (data not shown).

Finally, transcriptional changes of the defense-related CHS and PR1 genes in the roots were assessed. As for PAL1 and DIR1, both genes were significantly induced by the pathogen and increased between 12 and $72 \mathrm{hpi}$. When the response was compared in the treatment with mycorrhiza (+AMF+Mp), premycorrhized plantlets showed significantly higher expression levels of PR1 than roots in the nonmycorrhized plantlets at 12 hpi. However, this difference leveled off as the pathogen infection proceeded. The expression levels of CHS and PR1 were not significantly different at 24 and $72 \mathrm{hpi}$, although they were higher in $+\mathrm{AMF}+\mathrm{Mp}$ treatment.

\section{Total lignin content evaluation.}

Considering the overexpression of two key genes of the phenylpropanoid pathway $(P A L 1$ and $C H S)$ in premycorrhized plantlets, which could lead to pathogen resistance or tolerance, total (acid-soluble and insoluble) lignin was quantified (shown as a percentage) in the roots 24 hpi with M. phaseolina (Fig. 6). No differences were noticed in percent lignin between the control (i.e., $-\mathrm{AMF}-\mathrm{Mp}$ ) and $+\mathrm{AMF}+\mathrm{Mp}$ treatments. Conversely, the percent lignin in the $+\mathrm{AMF}-\mathrm{Mp}$ and $-\mathrm{AMF}+\mathrm{Mp}$ treatments was 10 and $20 \%$ lower, respectively, as compared with the $-\mathrm{AMF}-\mathrm{Mp}$ and $+\mathrm{AMF}+\mathrm{Mp}$ treatments.

\section{DISCUSSION}

In the present study, plant gene-expression profiles in bi(soybean + AMF and soybean $+M$. phaseolina $)$ or tripartite (soybean $+\mathrm{AMF}+$ M. phaseolina) interactions were analyzed using the mycelium donor plant (MDP) in-vitro culture system developed by Voets et al. (2009).

The MDP in-vitro culture system has been recently proposed as a suitable tool for studying the interactions between plant and $\mathrm{AMF}$ or between plant, AMF, and pathogen (Giachero et al. 2017), allowing a straightforward nondestructive observation of a belowground interaction. This system facilitates the analyses of plant responses to fungi without the interference of other microorganisms, which has been a problem for mycorrhizal studies in pots (Cameron et al. 2013). Interestingly, in-vitro cultivation systems have also been proven adequate for monitoring the initial stages of root infection by $M$. phaseolina (Bressano et al. 2010). Chowdhury et al. (2014) further investigated the infection process of $M$. phaseolina in resistant and susceptible varieties of sesame (Sesamum indicum).

In our in-vitro experiments, we confirmed the presence of $M$. phaseolina in the roots of premycorrhized and nonmycorhized plantlets and their infectivity under these conditions. Although all the plantlets showed a significant increase in the biomass of $M$. phaseolina in roots, the pathogen biomass was similar in $+\mathrm{AMF}+\mathrm{Mp}$ and $-\mathrm{AMF}+\mathrm{Mp}$ treatments during the time course of the study. M. phaseolina growth was very profuse, causing symptoms in premycorrhizal and nonmycorrhizal plantlets. However, the size and color of the lesions were more intense in $-\mathrm{AMF}+\mathrm{Mp}$ treatment at $72 \mathrm{hpi}$. The fact that there was no significant difference in pathogen biomass in mycorrhizal and nonmycorrhizal roots but symptoms were reduced in the presence of the AMF is clear evidence that we are in the presence of a mycorrhizal-induced tolerance more than a phenomenon of resistance. These results agree with previous studies demonstrating that AMF were able to enhance the tolerance of soybean plants to $M$. phaseolina, alleviating oxidative damage generated by the pathogen infection, even if the AMF was not able to avoid pathogen infection (Spagnoletti et al. 2016).

Several studies have reported that, after recognition between plant and beneficial or pathogenic microorganisms, different signaling pathways are induced in the plant (Afkhami and Stinchcombe 2016; Liu et al. 2007; Mah et al. 2012; Zamioudis and Pieterse 2012; Zuluaga et al. 2016). Indeed, important changes in gene expression and metabolic profiles have been shown in roots upon mycorrhizal colonization in different plant species (Dermatsev et al. 2010; Handa et al. 2015; Laparre et al. 2014).

Coincidently, we observed many transcriptional changes in soybean roots after 14 days of interaction with the AMF. Those changes were mainly related to development, signaling, biosynthesis of secondary metabolites, i.e., flavonoids, and biotic stress genes. As in previous reports from other plant systems (Güimil et al. 2005; Hohnjec et al. 2005; Liu et al. 2008; Rech

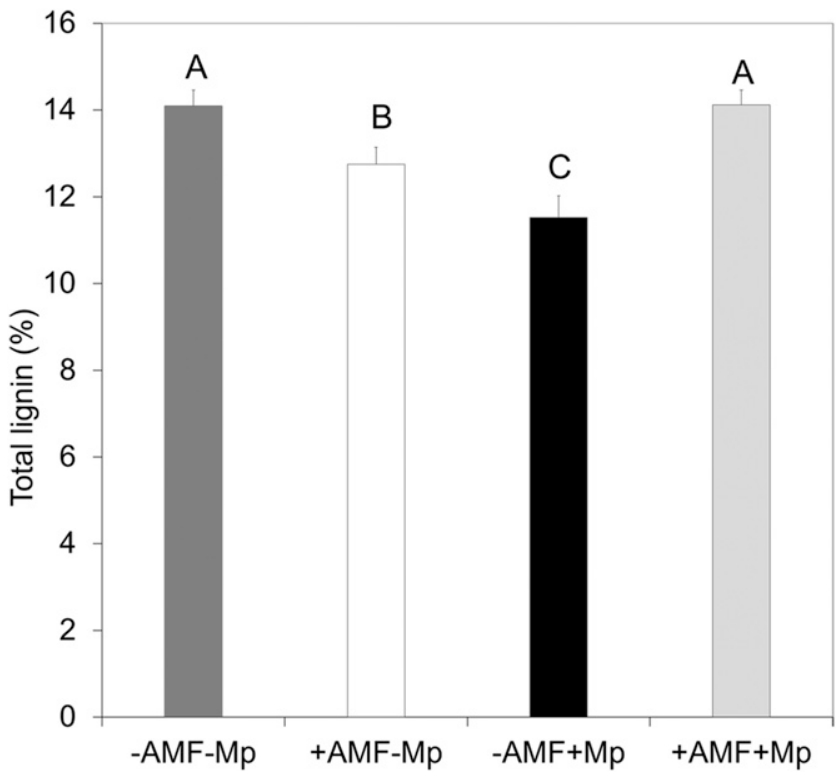

Fig. 6. Total lignin as percentage of root dry weight of premycorrhized plantlets inoculated with Macrophomina phaseolina $(+\mathrm{AMF}+\mathrm{Mp})$ or not $(+\mathrm{AMF}-\mathrm{Mp})$ and in roots of nonmycorrhized plantlets inoculated with M. phaseolina $(-\mathrm{AMF}+\mathrm{Mp})$ or not $(-\mathrm{AMF}-\mathrm{Mp})$ at $24 \mathrm{~h}$ postinoculation. Data are means of four biological replicates $(n=4)$. Error bars represent standard error. Different letters indicate significant differences at $P \leq 0.05$ (DGC comparison method). 
et al. 2013), genes related to serine carboxipeptidase-like (SCPL) and lectin precursors were highly induced in the premycorrhized plantlets (+AMF-Mp and $+\mathrm{AMF}+\mathrm{Mp})$. These genes are also induced in response to other microorganisms or to environmental stimuli and are believed to participate in the plant defense response (Bouwmeester et al. 2011; De Hoff et al. 2009; Guo et al. 2013; Huang et al. 2014; Liu et al. 2008; Mugford et al. 2009; Nivedita 2017; Singh et al. 2012). In animal systems, lectins and proteases form together the complement system, which plays a fundamental role as part of the innate immune system (Fujita et al. 2004). In our study, SCPL and lectin precursors showed elevated levels in premycorrhized plantlets, while pathogen infection did not alter their levels at 72 hpi. However, other studies in soybean showed the induction of a lectin protein kinase after an incompatible interaction with a parasitic nematode (Klink et al. 2007).

Considering a potential role in defense (Lannoo and Van Damme 2014), whether they may contribute to a better defense response in mycorrhizal plants remains to be addressed.

Our results demonstrated a significant impact of $M$. phaseolina infection on gene expression. It is already known that, upon pathogen attack, plants activate a number of mechanisms in an attempt to stop or to reduce the damages caused by the pathogen (Dodds and Rathjen 2010; Mah et al. 2012; Pusztahelyi et al. 2015). In the present study, we evidenced the upregulation of numerous plant defense genes related to signaling hormones, PR proteins, disease-resistance proteins, transcription factors, and secondary metabolism-related genes. Moreover, we found differences in the response of mycorrhizal and nonmycorrhizal plants to the pathogen. A remarkable aspect is the lower number of upregulated genes in premycorrhized plantlets compared with nonmycorrhized ones, following inoculation by $M$. phaseolina. As a matter of fact, in most of the coregulated genes, the impact on the FC was higher as well. Only a small set of genes showed higher expression in mycorrhizal plants, such as those coding for DIR-like protein and GST, potentially involved in the alleviation of oxidative damage, while most of the others were unknown. Remarkably, the proportion of genes with uncharacterized function is almost double in the $+\mathrm{AMF}+\mathrm{Mp}$ primed genes set (80 versus $40 \%$ in the other treatments). These genes are potentially involved in the enhanced tolerance observed in mycorrhizal plants and may reflect the largely uncharacterized responses underlying induced tolerance in plants.

Changes in gene-expression profiles in response to pathogens can underlie enhanced resistance against pathogens. In fact, priming of defense response is one of the mechanisms proposed to mediate the induced resistance against pathogens triggered by beneficial microbes, including mycorrhiza (Pieterse et al. 2014). However, although priming of plant defense responses in mycorrhizal plants have been shown in other systems, our microarray analysis did not show a significant primed response to the pathogen at the timepoint under study ( $72 \mathrm{hpi}$ ). It is possible that the timepoint analyzed was too late to study early plant-defense responses, since priming is characterized by an accelerated defense response (Conrath 2009; Martinez-Medina et al. 2016; Mauch Mani et al. 2017). Considering that the invitro system allowed a rapid colonization of the roots by the pathogen, it was tempting to speculate that the differences in response to the pathogen could be more evident at earlier timepoints. Following this hypothesis, we carried out a new experiment, with the same treatments, and a time course analysis was performed.

In this study, four genes involved in defense mechanisms, $D I R, P A L 1, C H S$, and PR1, were evaluated at 12, 24, and $72 \mathrm{hpi}$ with $M$. phaseolina. At 12 hpi, roots of premycorrhized plantlets showed higher transcription levels of the defense genes analyzed than nonmycorrhizal roots. This trend was still visible at 24 and $72 \mathrm{hpi}$, nevertheless, this pattern reverted for $P A L 1$ at 72 hpi.

Several studies depict an induced expression of DIR and DIR-like genes upon pathogen infection, suggesting a role of DIRs in adaptive responses (Borges et al. 2013; Coram et al. 2008; Ponce de León and Montesano 2013; Thamil Arasan et al. 2013; Zhu et al. 2007). DIR proteins were shown to mediate regio- and stereoselectivity of bimolecular phenoxy radical coupling (Davin et al. 1997) and are involved in numerous biological processes, including one or both, cell wallmetabolism modification and production of antibacterial compounds (Paniagua et al. 2017).

Although not significant in the second experiment, DIR expression levels were slightly higher in mycorrhizal plants, at every timepoint tested, upon pathogen inoculation, reaching maximum induction at $72 \mathrm{hpi}$. This increase in DIR expression could be associated to an induction and interplay of the defense response to the infection by the pathogen. In this scenario, DIR proteins could support cell-wall reinforcement and, thus, restrict or block M. phaseolina invasion, as reported for other plant-pathogen interactions (Ponce de León et al. 2012; Ralph et al. 2006; Shi et al. 2012; Thamil Arasan et al. 2013). Borges et al. (2013) hypothesized that low level of DIR expression during the early stages of fungal infection allows lignin biosynthesis to build up physical barriers. Whereas, the upregulation of DIR genes during later stages of infection increases antifungal activities through activation of lignin biosynthesis.

The sudden increase of the transcription levels in two key genes of the phenylpropanoid pathway (PAL1 and $C H S$ ) in premycorrhized plantlets could lead to the increased accumulation of total phenols and lignin. Derivative products of this pathway, such as lignin and flavonoids, act as a plant protectant against biotic and abiotic stresses (Dixon and Paiva 1995). Particularly, the lignification process may be an important step toward pathogen resistance or tolerance, either through lignin deposition or through formation of lignin-like compounds. Therefore, total lignin was evaluated. As result, we found a reduction in the amounts of lignin in the $-\mathrm{AMF}+\mathrm{Mp}$ treatment that could be a consequence of host manipulation by the pathogen. However, this hypothetical disruption of lignin metabolism was not observed in the +AMF+Mp treatment, suggesting that $M$. phaseolina was not able to increase the susceptibility of mycorrhizal plants to promote its invasion. Actually, there are evidences demonstrating that application of thiamine and riboflavin contribute to control charcoal rot of soybean through increased activity of defense-related enzymes (PAL, PR, peroxidase, and polyphenol oxidase) and increased accumulation of total phenols and lignin in soybean plants infected with M. phaseolina (Abdel-Monaim 2011).

Soybean infection by $M$. phaseolina also resulted in the upregulation of SA-associated $P R I$ defense gene expression. The number of transcripts increased in roots of both pre- and nonmycorrhized soybean plantlets. However, premycorrhized plantlets showed a faster response as compared with the nonmycorrhized ones, as demonstrated by the higher transcription level of PR1 at 12 hpi. This corroborates the study of Gallou et al. (2011) showing the priming of two PR genes (PRI and $P R 2)$ in premycorrhized potato plantlets challenged with $P h y-$ tophthora infestans.

At $72 \mathrm{hpi}$, we observed a decrease in the transcription level of PAL1 in the +AMF+Mp treatment. This decrease can be explained by the absence of newly synthesized transcripts added to the natural turnover of mRNAs.

Under this scenario, it could be postulated that after M. phaseolina infection, premycorrhized plantlets demonstrated the great capacity 
of gene transcription regulation under conditions of disease pressure. Meanwhile, nonmycorrhizal plantlets had a direct induction of defense after pathogen challenge. These results are relevant, since plant defense response implies a metabolic cost, which could be associated to a negative impact on biomass and seed production (Denancé et al. 2013; Walters and Heil 2007).

In conclusion, our transcriptomic data provides information on the important changes in gene expression occurring in soybean plants upon interaction with mycorrhizal fungi or the pathogen M. phaseolina. Specific transcriptomic changes found in mycorrhizal plants may be associated with the modulation of $M$. phaseolina infestation of the roots, for example, by enhancing pathogen recognition capacity through SCPL and lectin induction and allowing an earlier defense response, leading to a better cellular homeostasis in plantlets for an optimum utilization of photosynthates (Barea et al. 2002). We are convinced that the generated data will yield many opportunities for further biological experimentation to confirm the new hypotheses in more natural root environments provided in pot cultures and field experiments.

The detailed insights of soybean-AMF-M. phaseolina triple interaction presented here will contribute to understanding the complexity of plant responses to different organisms and their implications to biocontrol and will eventually lead to the design and optimization of sustainable agronomic practices, strengthened by existing plant-microbial interactions.

\section{MATERIALS AND METHODS}

\section{Biological material.}

A culture of Rhizophagus irregularis (Błaszk, Wubet, Renker \& Buscot) Schüßler and Walker (2010) (as 'irregulare') MUCL 41833 was supplied by the Glomeromycota In Vitro Collection associated to Ri T-DNA-transformed root organ cultures of carrot (Daucus carota L. clone DC2). The strain was maintained in petri plates (90 mm diameter) on modified Strullu Romand (MSR) medium (Declerck et al. 1998) solidified with $3 \mathrm{~g}$ of Phytagel (Sigma-Aldrich, St. Louis) per liter, as detailed by Cranenbrouck et al. (2005). The petri plates were incubated in the dark in an inverted position at $27^{\circ} \mathrm{C}$ for several months, until thousands of spores were obtained.

The Mycothèque de l'Université catholique de Louvain (MUCL) supplied a culture of Macrophomina phaseolina (Tassi) Goidanich MUCL 53604 on potato dextrose agar (Scharlau Chemie S.A, Barcelona, Spain). The petri plates were incubated at $25^{\circ} \mathrm{C}$ in the dark for 7 days.

Seeds of Medicago truncatula Gaertn. cv. Jemalong A 17 (South Australian Research and Development Institute, Urrbrae, Australia) were surface-disinfected by immersion in calcium hypochlorite ( $3.5 \%$ active calcium) for $12 \mathrm{~min}$, were rinsed three time in deionized sterilized water $\left(121^{\circ} \mathrm{C}\right.$ for $\left.15 \mathrm{~min}\right)$, and were germinated in groups of 13 on petri plates $(90 \mathrm{~mm}$ in diameter) filled with $35 \mathrm{ml}$ of MSR medium without sucrose and vitamins and solidified with $3 \mathrm{~g}$ of Phytagel per liter. The petri plates were incubated at $27^{\circ} \mathrm{C}$ in the dark for 4 days and were subsequently exposed to light for 1 day, before use.

Seeds of soybean Glycine max (L.) Merr. cv. Don Mario 4800 were surface-disinfected by immersion in ethanol $70 \%$ for $1 \mathrm{~min}$ and sodium hypochlorite (8\% active chlorine) for $2 \mathrm{~min}$. Both steps were followed by rinsing three times in deionized sterilized water $\left(121^{\circ} \mathrm{C}\right.$ for $\left.15 \mathrm{~min}\right)$. Seeds were subsequently germinated in groups of six on petri plates $(145 \mathrm{~mm}$ in diameter) filled with $60 \mathrm{ml}$ of MSR medium without sucrose and vitamins and solidified with $3 \mathrm{~g}$ of Phytagel per liter. The petri plates were exposed to light for 1 day and were subsequently incubated at $27^{\circ} \mathrm{C}$ in the dark for 4 days, before use.

\section{Experimental set up for microarray experiment.}

The MDP in-vitro culture system, developed by Voets et al. (2009) for fast and homogenous AMF colonization of $M$. truncatula plantlets, was adapted to soybean and was used in the experimental set up. Briefly, a bi-compartmented culture plate was constructed by placing the cover of a 55-mm diameter petri plate (named root compartment [RC]) into the base of a $145-\mathrm{mm}$ diameter petri plate (named hyphal compartment $[\mathrm{HC}])$. The two compartments were thus physically separated by the wall of the 55-mm petri plate. Both compartments were subsequently filled with MSR medium $(20$ and $100 \mathrm{ml}$ in the $\mathrm{RC}$ and $\mathrm{HC}$, respectively) lacking sucrose and vitamins and solidified with $3 \mathrm{~g}$ of Phytagel per liter. Five -day-old M. truncatula seedlings were transferred to the RC with their roots plated on the surface of the MSR medium and shoot extending outside the culture plate via a hole. A plug $(9 \times$ $5 \mathrm{~mm}$ ) of MSR medium containing \pm 100 spores of $R$. irregularis MUCL 41833 was placed in the vicinity of the roots. The culture plates were then sealed with Parafilm (Pechiney Plastic Packaging, Chicago) and the holes were plastered with sterilized $\left(121^{\circ} \mathrm{C}\right.$ for $\left.15 \mathrm{~min}\right)$ silicon grease (VWR International, Leuven, Belgium) to avoid contaminations. The culture plates were covered with an opaque plastic bag to keep the AMF and M. truncatula roots in the dark, while the shoots developed under light conditions. The culture plates were transferred to a growth chamber set at $20^{\circ} \mathrm{C}$ (day) and $18^{\circ} \mathrm{C}$ (night), $70 \%$ relative humidity, with a photoperiod of $16 \mathrm{~h}$ per day and a photosynthetic photon flux of $225 \mu \mathrm{mol} \mathrm{m}^{-2} \mathrm{~s}^{-1}$. In total, 50 culture plates were set up.

After approximately six weeks of association, the AMF mycelium crossed the plastic wall separating the $\mathrm{RC}$ from the $\mathrm{HC}$ and developed a profuse extraradical mycelium (ERM) network bearing numerous spores in the HC. At week 8, a new hole was made in the base and the lid of the $\mathrm{HC}$ and a 5 days old soybean plantlet was inserted in the culture plate with the roots in direct contact with the ERM and the shoot extending outside the culture plate. In parallel and following strictly the same protocol and timing, soybean plantlets were inserted in culture plates without AMF (i.e., the control treatment). The culture plates were then sealed carefully and were incubated in a growth chamber under the same conditions as above. After 7 days, the RC (i.e., the 45-mm diameter petri plate) of all the culture plates were removed with forceps, leaving a hole that was immediately refilled with $30 \mathrm{ml}$ of solid MSR medium without sucrose and vitamins and solidified with $3 \mathrm{~g}$ of Phytagel per liter. Two weeks later, the culture plates with and without AMF were randomly divided in two groups. Half of the culture plates were inoculated with $M$. phaseolina, using four plugs ( $3 \mathrm{~mm}$ in diameter), from a 7-day-old culture, the other half remaining free of the pathogen. Treatments are represented by two levels of two factors. Four treatments were thus considered: premycorrhized soybean plantlets inoculated $(+\mathrm{AMF}+\mathrm{Mp})$ or not (+AMF-Mp) with $M$. phaseolina and nonmycorrhizal soybean plantlets inoculated $(-\mathrm{AMF}+\mathrm{Mp})$ or not $(-\mathrm{AMF}-\mathrm{Mp})$ with $M$. phaseolina. The plants were harvested 72 hpi with M. phaseolina. Six independent biological replicates were used per treatment. Half of the root material was used to estimate colonization by AMF or infection by M. phaseolina or both and the other half for RNA extraction and was stored at $-80^{\circ} \mathrm{C}$, until use.

\section{RNA extraction.}

Total RNA was extracted with the RNeasy plant mini kit (Qiagen, Valencia, CA, U.S.A.) according to the manufacturer's instructions. The total RNA was treated with the TURBO DNA-free kit (Ambion, Austin, TX, U.S.A.), according to the manufacturer's instructions. Concentration and purity 
of total RNA were determined in a NanoDrop-ND 1000 UV-vis spectrophotometer (NanoDrop Technologies, Wilmington, DE, U.S.A.), and the total RNA quality was tested using the Agilent 2100 BioAnalyzer, as recommended by the manufacturer's protocol (RNA 6000 nano assay protocol) (Agilent Technologies, Santa Clara, CA, U.S.A.). For each treatment, total RNA of two replicates were selected and pooled (i.e., biological replicate). Thus, three independent biological replicates were used per treatment for microarray experiment.

\section{cDNA labeling and microarray hybridization.}

Synthesis of cDNA and labeling was performed with Quick Amp labeling kit, as described in the protocol (Agilent Technologies Inc.). A two-color microarray-based gene expression analysis protocol was used. Labeled cDNA targets ( $\mathrm{Cy} 3$ and Cy5) were fragmented at $60^{\circ} \mathrm{C}$ for $30 \mathrm{~min}$ and were then hybridized to the oligonucleotide arrays (Agilent 016772 G. max Oligo Microarray $4 \times 44 \mathrm{~K})$ at $65^{\circ} \mathrm{C}$ for $17 \mathrm{~h}$. All treatment replicates (including $-\mathrm{AMF}-\mathrm{Mp}$ ) were hybridized with a pull of the three biological replicates of -AMF-Mp treatment (competitive hybridization).

Hybridization and washing of slides were conducted according to the manufacturer's protocols. The hybridized slides were scanned using the scanner Agilent G2505B at high resolution of $5 \mu \mathrm{m}$ at wavelengths of $532(\mathrm{Cy} 3)$ and $633 \mathrm{~nm}$ (Cy5) (Agilent Technologies, Inc.). Microarray images were imported in the Agilent Feature Extraction software (version 9.1.3.1) and were aligned with the appropriate array grid template file (015425_D_F_20061105; Agilent Technologies, Inc.).

The microarrays were hybridized, stained, washed, and scanned at the Institute of Life Science of the MUCL (Agilent microarray platform).

\section{Preprocessing of microarray data.}

Data preprocessing was performed using the limma library (Smyth 2005) from the R package (The R Project for Statistical Computing). Background correction was performed, using background Correct function, using the "rma" algorithm. Between arrays, normalization was performed, using normalize Between Array function, using "quantile" method. Finally, gene expressions were transformed to $\log _{2}$ scale and summarization of technical replicates was done calculating the median. The selected comparison among treatments was performed by appropriate contrasts (+AMF-Mp versus $-\mathrm{AMF}-\mathrm{Mp},-\mathrm{AMF}$ $+\mathrm{Mp}$ versus $-\mathrm{AMF}-\mathrm{Mp},+\mathrm{AMF}+\mathrm{Mp}$ versus $-\mathrm{AMF}-\mathrm{Mp}$, and $+\mathrm{AMF}+\mathrm{Mp}$ versus $-\mathrm{AMF}+\mathrm{Mp}$ ). Because of the $\log _{2}$ transformation of gene expressions, the estimated contrasts were expressed in logtwofold change scale. To express the contrast differences as 'fold change', the following transformation was applied: $\mathrm{FC}=2^{\text {contrast }}$ when the contrast was $\geq 0$ and $-2^{- \text {contrast }}$ when the contrast was $<0$. This way, $\mathrm{FC}$ values have positive as well as negative values. A FC of 4 means a $4 \times$ increase of gene expression, meanwhile a value of -4 means a $4 \times$ decrease. Genes were considered as differentially regulated if $P$ value of $\leq 0.005$ and FC values were $\geq 3.0$ or $\leq 3$.

The microarray data have been deposited in the National Center for Biotechnology Information Gene Expression Omnibus (GEO) database and are accessible through GEO series accession number GSE87740.

\section{Gene Ontology (GO) analysis.}

For GO analysis, two freely available software programs on the MapMan Site of Analysis website were used, namely, Mercator Automated Sequence Annotation Pipeline and MapMan. The first generates functional predictions for each input gene to propose a functional 'Bin' based on the manually curated binning of the reference database entries. The second enables easier data visualization and interpretation of soybean gene expression involved in biotic stress.

\section{Experimental set up for microarray validation.}

For microarray validation, a new experiment was set up following the protocol described above. Four treatments, each with four replicates, were considered: Premycorrhized soybean plantlets inoculated $(+\mathrm{AMF}+\mathrm{Mp})$ or not $(+\mathrm{AMF}-\mathrm{Mp})$ with $M$. phaseolina and nonmycorrhizal soybean plantlets inoculated $(-\mathrm{AMF}+\mathrm{Mp})$ or not $(-\mathrm{AMF}-\mathrm{Mp})$ with M. phaseolina. Soybean plantlets were harvested 12,24 , and 72 hpi with $M$. phaseolina. Half of the root material was used to confirm colonization by $\mathrm{AMF}$ and the other half was stored at $-80^{\circ} \mathrm{C}$ until use.

Total RNA from frozen roots was extracted and was purified as described above. RT of $500 \mathrm{ng}$ of total RNA was performed with the Transcriptor High Fidelity cDNA synthesis kit (Roche, Montreal, Canada), in a volume of $20 \mu \mathrm{l}$ with oligo $(\mathrm{dT})_{18}$ primer, at $55^{\circ} \mathrm{C}$ for $20 \mathrm{~min}$, according to the manufacturer's instructions. Four independent biological replicates with at least two technical replicates were analyzed per treatment, per timepoint. For each RNA sample, a reaction without RT was performed as a control for contamination by genomic DNA.

\section{Real-time qPCR.}

Five targeted genes were selected, a lectin precursor (BI497881.1), DIR (BU549825.1), PAL1 (X52953), CHS (XM_003537805), and PR1 (NM_001251239). Real-time PCR analysis was performed, using the iCycler iQ5 system (BioRad, Munich) and primers specifically designed in this study for SYBR green assay. Relative quantification of specific mRNA levels was performed using the comparative $2^{-\Delta \Delta \mathrm{Ct}}$ method (Livak and Schmittgen 2001). Expression values were normalized using the housekeeping gene Skipl6 (CD397253.1), which has been shown to be the most stable during qPCR, under different stress conditions, in soybean roots (Hu et al. 2009). The amount of transcripts was depicted as relative to the control level of expression (nonmycorrhized soybean plantlets noninoculated with $M$. phaseolina). The DGC test model was conducted to identify significant differences $(P \leq 0.05)$ between the groups.

\section{Evaluation of AMF root colonization.}

The root systems were cleared in $10 \% \mathrm{KOH}$ at room temperature for $3 \mathrm{~h}$, were rinsed with distilled water, were bleached and acidified with $1 \% \mathrm{HCl}$, and were stained with trypan blue $0.2 \%$ at room temperature for $15 \mathrm{~min}$. The root systems were subsequently mounted on microscope slides, and 200 intersections were observed under a dissecting microscope (Olympus $\mathrm{BH} 2$, Olympus Optical, GmbH, Germany) at 10 to $40 \times$ magnifications. Total RC (\% RC), abundance of arbuscules $(\% \mathrm{~A})$, and intraradical spores and vesicles $(\% \mathrm{~V})$ were determined according to McGonigle et al. (1990). The DGC test model was conducted to identify significant differences $(P \leq 0.05)$ between the groups.

\section{M. phaseolina infection.}

M. phaseolina biomass in infected roots at 12,24 , and $72 \mathrm{hpi}$ was determined as was previously described for Verticillium spp. (Santhanam et al. 2013).

Briefly, total genomic DNA was extracted from frozen roots, using the innuPREP Plant DNA kit (Analytik, Jena, Germany) and following manufacturer recommendations. Concentration and purity of total DNA were determined in a NanoDrop-ND 1000 UV-vis spectrophotometer (NanoDrop Technologies). 
Real-time PCR amplifications on total genomic DNA extracted from roots were carried out using the iCycler iQ5 system (Bio-Rad) and M. phaseolina-specific primers (MpSyK) for SYBR green assay (Babu et al. 2011). The concentrations of fungal DNA in experimental treatments were calculated by comparing cycle threshold values to the crossing point values of the linear regression line of the standard curve and relative to $12 \mathrm{hpi}$ of the $-\mathrm{AMF}+\mathrm{Mp}$ treatment level. The DGC test model was conducted to identify significant differences $(P \leq 0.05)$ between the groups.

To demonstrate the infective potential of M. phaseolina, six additional culture plates with nonmycorrhized and premycorrhized soybean plantlets were inoculated with the pathogen, using four plugs ( $3 \mathrm{~mm}$ diameter) from a 7-day-old M. phaseolina culture. The timing of infection and associated symptoms on the entire root system were monitored nondestructively, with a binocular microscope (Olympus SZ61), through the culture plate lid. Images of roots were captured with a Canon PowerShot SX160 IS digital camera.

\section{Lignin extraction and quantification.}

Total (acid-soluble and insoluble) lignin extraction and quantification was carried out starting from $500 \mathrm{mg}$ of soybean roots, according to the protocol of Sluiter et al. (2008), at the Biological and Industrial Chemistry Unit of Gembloux Agro Bio-Tech (Université de Liège, Belgium). The values are expressed as percentage (\%) of lignin per root dry weight. The DGC test model was conducted to identify significant differences $(P \leq 0.05)$ between the groups.

\section{Statistical analysis.}

Gene expression data (i.e., relative expression ratio) were analyzed for microarray analysis and qPCR, using two-way and three-way analysis of variance, respectively (ANOVA II and ANOVA III). Percentages of AMF root colonization, pathogen quantification, and total lignin content were analyzed using one-way analysis of variance (ANOVA I). ANOVA was performed using the software InfoStat (Di Rienzo et al. 2013). Comparisons between treatments were performed by the DGC test (Di Rienzo et al. 2002).

\section{LITERATURE CITED}

Abdel-Monaim, M. F. 2011. Role of riboflavin and thiamine in induced resistance against charcoal rot disease of soybean. Afr. J. Biotechnol. 1053:10842-10855

Afkhami, M. E., and Stinchcombe, J. R. 2016. Multiple mutualist effects on genomewide expression in the tripartite association between Medicago truncatula, nitrogen-fixing bacteria and mycorrhizal fungi. Mol. Ecol. 25:4946-4962.

Arora, M., and Pareek, S. 2013. Effect of soil moisture and temperature on the severity of Macrophomina charcoal rot up-reof sorghum. Indian J. Soc. Res. 41:155.

Azcón-Aguilar, C., and Barea, J. M. 1997. Arbuscular mycorrhizas and biological control of soil-borne plant pathogens-An overview of the mechanisms involved. Mycorrhiza 6:457-464.

Babu, B. K., Mesapogu, S., Sharma, A., Somasani, S. R., and Arora, D. K. 2011. Quantitative real-time PCR assay for rapid detection of plant and human pathogenic Macrophomina phaseolina from field and environmental samples. Mycologia 103:466-473.

Backman, P. A., and Sinclair, J. B. 1989. Compendium of Soybean Diseases. The American Phytopathological Society, St. Paul, MN, U.S.A

Barea, J. M., Azcón, R., and Azcón-Aguilar, C. 2002. Mycorrhizosphere interactions to improve plant fitness and soil quality. Antonie van Leeuwenhoek 81:343-351.

Borges, A. F., Ferreira, R. B., and Monteiro, S. 2013. Transcriptomic changes following the compatible interaction Vitis vinifera-Erysiphe necator. Paving the way towards an enantioselective role in plant defence modulation. Plant Physiol. Biochem. 68:71-80.

Bouwmeester, K., de Sain, M., Weide, R., Gouget, A., Klamer, S., Canut, H., and Govers, F. 2011. The lectin receptor kinase LecRK-I.9 is a novel
Phytophthora resistance component and a potential host target for a RXLR effector. PLoS Pathog. 7:e1001327.

Bressano, M., Giachero, M. L., Luna, C. M., and Ducasse, D. A. 2010. An in vitro method for examining infection of soybean roots by Macrophomina phaseolina. Physiol. Mol. Plant Pathol. 74:201-204.

Cameron, D. D., Neal, A. L., van Wees, S. C. M., and Ton, J. 2013. Mycorrhiza-induced resistance: More than the sum of its parts? Trends Plant Sci. 18:539-545.

Campos-Soriano, L., García-Martínez, J., and San Segundo, B. 2012. The arbuscular mycorrhizal symbiosis promotes the systemic induction of regulatory defence-related genes in rice leaves and confers resistance to pathogen infection. Mol. Plant Pathol. 13:579-592.

Cely, M. V., de Oliveira, A. G., de Freitas, V. F., de Luca, M. B., Barazetti, A. R., dos Santos, I. M., Gionco, B., Garcia, G. V., Prete, C. E. C., and Andrade, G. 2016. Inoculant of arbuscular mycorrhizal fungi (Rhizophagus clarus) increase yield of soybean and cotton under field conditions. Front. Microbiol. 7:720.

Chowdhury, S., Basu, A., Chaudhuri, T. R., and Kundu, S. 2014. In vitro characterization of the behaviour of Macrophomina phaseolina (Tassi) Goid at the rhizosphere and during early infection of roots of resistant and susceptible varieties of sesame. Eur. J. Plant Pathol. 138:361-375.

Conrath, U. 2009. Priming of induced plant defense responses. Adv. Bot. Res. 51:361-395.

Conrath, U., Beckers, G. J., Langenbach, C. J., and Jaskiewicz, M. R. 2015. Priming for enhanced defense. Annu. Rev. Phytopathol. 53:97-119.

Coram, T. E., Wang, M., and Chen, X. 2008. Transcriptome analysis of the wheat-Puccinia striiformis f. sp. tritici interaction. Mol. Plant Pathol. 9: 157-169.

Cranenbrouck, S., Voets, L., Bivort, C., Renard, L., Strullu, D. G., and Declerck, S. 2005. Methodologies for in vitro cultivation of arbuscular mycorrhizal fungi with root organs. Pages 341-375 in: In vitro culture of mycorrhizas. Springer, Berlin.

Dar, M. H., and Reshi, Z. A. 2017. Vesicular arbuscular mycorrhizal (VAM) fungi-as a major biocontrol agent in modern sustainable agriculture system. Russ. Agric. Sci. 43:138-143.

Davin, L. B., Wang, H. B., Crowell, A. L., Bedgar, D. L., Martin, D. M., Sarkanen, S., and Lewis, N. G. 1997. Stereoselective bimolecular phenoxy radical coupling by an auxiliary (dirigent) protein without an active center. Science 275:362-367

De Hoff, P. L., Brill, L. M., and Hirsch, A. M. 2009. Plant lectins: The ties that bind in root symbiosis and plant defense. Mol. Genet. Genomics 282:1-15.

Declerck, S., Strullu, D. G., and Plenchette, C. 1998. Monoxenic culture of the intraradical forms of Glomus sp. isolated from a tropical ecosystem: A proposed methodology for germplasm collection. Mycologia 90:579-585.

Declerck, S., Willems, A., van der Heijden, M. G. A., Varese, G. C., Turkovskaya, O., Evtushenko, L., Ivshina, I., and Desmeth, P. 2015. PERN: An EU-Russia initiative for rhizosphere microbial resources. Trends Biotechnol. 33:377-380.

Denancé, N., Sánchez-Vallet, A., Goffner, D., and Molina, A. 2013. Disease resistance or growth: The role of plant hormones in balancing immune responses and fitness costs. Front. Plant Sci. 4:155

Dermatsev, V., Weingarten-Baror, C., Resnick, N., Gadkar, V., Wininger, S., Kolotilin, I., Mayzlish-Gati, E., Zilberstein, A., Koltai, H., and Kapulnik, Y. 2010. Microarray analysis and functional tests suggest the involvement of expansins in the early stages of symbiosis of the arbuscular mycorrhizal fungus Glomus intraradices on tomato (Solanum lycopersicum). Mol Plant Pathol. 11:121-135.

Di Rienzo, J. A., Casanoves, F., Balzarini, M. G., Gonzalez, L., Tablada, M., and Robledo, C. W. 2013. InfoStat versión 2013. Grupo InfoStat, FCA, Universidad Nacional de Córdoba, Córdoba, Argentina. http://www. infostat.com.ar

Di Rienzo, J. A., Guzmán, A. W., and Casanoves, F. 2002. A multiplecomparisons method based on the distribution of the root node distance of a binary tree. J. Agric. Biol. Environ. Stat. 7:129-142.

Dixon, R. A., and Paiva, N. L. 1995. Stress-induced phenylpropanoid metabolism. Plant Cell 7:1085-1097.

Dodds, P. N., and Rathjen, J. P. 2010. Plant immunity: Towards an integrated view of plant-pathogen interactions. Nat. Rev. Genet. 11:539-548.

Doley, K., Borde, M., Dudhane, M., and Jite, P. K. 2014. Efficiency of Glomus fasciculatum and Trichoderma viride in bio-control of soil-borne pathogen (Macrophomina phaseolina) on different groundnut cultivars. Bioscience Discovery 5:163-169.

Fortin, J. A., Bécard, G., Declerck, S., Dalpé, Y., St Arnaud, M., Coughlan, A. P., and Piché, Y. 2002. Arbuscular mycorrhiza on root-organ cultures. Can. J. Bot. 80:1-20.

Fujita, T., Matsushita, M., and Endo, Y. 2004. The lectin-complement pathwayIts role in innate immunity and evolution. Immunol. Rev. 198:185-202. 
Gallou, A., De Jaeger, N., Cranenbrouck, S., and Declerck, S. 2010. Fast track in vitro mycorrhization of potato plantlets allow studies on gene expression dynamics. Mycorrhiza 20:201-207.

Gallou, A., Declerck, S., and Cranenbrouck, S. 2012. Transcriptional regulation of defence genes and involvement of the WRKY transcription factor in arbuscular mycorrhizal potato root colonization. Funct. Integr. Genomics 12:183-198.

Gallou, A., Mosquera, H. P. L., Cranenbrouck, S., Suárez, J. P., and Declerck, S. 2011. Mycorrhiza induced resistance in potato plantlets challenged by Phytophthora infestans. Physiol. Mol. Plant Pathol. 76:20-26.

Giachero, M. L., Marquez, N., Gallou, A., Luna, C. M., Declerck, S., and Ducasse, D. A. 2017. An in vitro method for studying the three-way interaction between soybean, Rhizophagus irregularis and the soil-borne pathogen Fusarium virguliforme. Front. Plant Sci. 8:1033.

Gianinazzi, S., Gollotte, A., Binet, M. N., van Tuinen, D., Redecker, D., and Wipf, D. 2010. Agroecology: The key role of arbuscular mycorrhizas in ecosystem services. Mycorrhiza 20:519-530.

Giorda, L. M., Baigorri, H. E., Doucet, M. E., Viale, J. A., Forjan, H., Iriarte, L., and Tommaso, J. C. 1997. El cultivo de la soja en Argentina. Instituto de Tecnología Agropuecuaria (INTA), Centro Regional Córdoba, Argentina.

Güimil, S., Chang, H. S., Zhu, T., Sesma, A., Osbourn, A., Roux, C., Ioannidis, V., Oakeley, E. J., Docquier, M., Descombes, P., Briggs, S. P., and Paszkowski, U. 2005. Comparative transcriptomics of rice reveals an ancient pattern of response to microbial colonization. Proc. Natl. Acad. Sci. U.S.A. 102:8066-8070.

Guo, P., Wang, Y., Zhou, X., Xie, Y., Wu, H., and Gao, X. 2013. Expression of soybean lectin in transgenic tobacco results in enhanced resistance to pathogens and pests. Plant Sci. 211:17-22.

Gupta, G. K., Sharma, S. K., and Ramteke, R. 2012. Biology, epidemiology and management of the pathogenic fungus Macrophomina phaseolina (Tassi) Goid with special reference to charcoal rot of soybean Glycine $\max ($ L.) Merrill. J. Phytopathol. 160:167-180.

Handa, Y., Nishide, H., Takeda, N., Suzuki, Y., Kawaguchi, M., and Saito, K. 2015. RNA-seq transcriptional profiling of an arbuscular mycorrhiza provides insights into regulated and coordinated gene expression in Lotus japonicus and Rhizophagus irregularis. Plant Cell Physiol. 56:1490-1511.

Hartman, G. L., Sinclair, J. B., and Rupe, J. C. 1999. Compendium of soybean diseases No, 4th Ed. The American Phytopathological Society, St. Paul, MN, U.S.A.

Hartman, G. L., West, E. D., and Herman, T. K. 2011. Crops that feed the World 2. Soybean-worldwide production, use, and constraints caused by pathogens and pests. Food Secur. 3:5-17

Hohnjec, N., Vieweg, M. F., Pühler, A., Becker, A., and Küster, H. 2005. Overlaps in the transcriptional profiles of Medicago truncatula roots inoculated with two different Glomus fungi provide insights into the genetic program activated during arbuscular mycorrhiza. Plant Physiol. 137:1283-1301

Hooker, J. E., Jaizme-Vega, M., and Atkinson, D. 1994. Biocontrol of plant pathogens using arbuscular mycorrhizal fungi. Pages 191-200 in: Impact of Arbuscular Mycorrhizas on Sustainable Agriculture and Natural Ecosystems. Birkhäuser, Basel.

Hu, R., Fan, C., Li, H., Zhang, Q., and Fu, Y. F. 2009. Evaluation of putative reference genes for gene expression normalization in soybean by quantitative real-time RT-PCR. BMC Mol. Biol. 10:93.

Huang, P. Y., Yeh, Y. H., Liu, A. C., Cheng, C. P., and Zimmerli, L. 2014. The Arabidopsis LecRK-VI.2 associates with the pattern-recognition receptor FLS2 and primes Nicotiana benthamiana pattern-triggered immunity. Plant J. 79:243-255.

Islam, M. S., Haque, M. S., Islam, M. M., Emdad, E. M., Halim, A., Hossen, Q. M. M., Hossain, M. Z., Ahmed, B., Rahim, S., Rahman, M. S., Alam, M. M., Hou, S., Wan, X., Saito, J. A., and Alam, M. 2012. Tools to kill: Genome of one of the most destructive plant pathogenic fungi Macrophomina phaseolina. BMC Genomics 13:493.

Karthikeyan, B., Abitha, B., Henry, A. J., Sa, T., and Joe, M. M. 2016. Interaction of rhizobacteria with arbuscular mycorrhizal fungi AMF and their role in stress abetment in agriculture. Pages 117-142 in: Recent Advances on Mycorrhizal Fungi. M. Pagano, ed. Springer, Cham.

Kendig, S. R., Rupe, J. C., and Scott, H. D. 2000. Effect of irrigation and soil water stress on densities of Macrophomina phaseolina in soil and roots of two soybean cultivars. Plant Dis. 84:895-900.

Kishore Babu, B., Saxena, A. K., Srivastava, A. K., and Arora, D. K. 2007. Identification and detection of Macrophomina phaseolina by using species-specific oligonucleotide primers and probe. Mycologia 99: 797-803.

Klink, V. P., Overall, C. C., Alkharouf, N. W., MacDonald, M. H., and Matthews, B. F. 2007. A time-course comparative microarray analysis of an incompatible and compatible response by Glycine max (soybean) to
Heterodera glycines (soybean cyst nematode) infection. Planta 226: 1423-1447.

Lannoo, N., and Van Damme, E. J. 2014. Lectin domains at the frontiers of plant defense. Front. Plant Sci. 5:397.

Laparre, J., Malbreil, M., Letisse, F., Portais, J. C., Roux, C., Bécard, G., and Puech-Pagès, V. 2014. Combining metabolomics and gene expression analysis reveals that propionyl- and butyryl-carnitines are involved in late stages of arbuscular mycorrhizal symbiosis. Mol. Plant 7:554-566.

Liu, H., Wang, X., Zhang, H., Yang, Y., Ge, X., and Song, F. 2008. A rice serine carboxypeptidase-like gene OsBISCPL1 is involved in regulation of defense responses against biotic and oxidative stress. Gene 420:57-65.

Liu, J., Blaylock, L. A., Endre, G., Cho, J., Town, C. D., VandenBosch, K. A., and Harrison, M. J. 2003. Transcript profiling coupled with spatial expression analyses reveals genes involved in distinct developmental stages of an arbuscular mycorrhizal symbiosis. Plant Cell 15:2106-2123.

Liu, J., Maldonado-Mendoza, I., Lopez-Meyer, M., Cheung, F., Town, C. D., and Harrison, M. J. 2007. Arbuscular mycorrhizal symbiosis is accompanied by local and systemic alterations in gene expression and an increase in disease resistance in the shoots. Plant J. 50:529-544.

Livak, K. J., and Schmittgen, T. D. 2001. Analysis of relative gene expression data using real-time quantitative PCR and the $2^{-\Delta \Lambda C(T)}$ method. Methods 25:402-408.

López-Ráez, J. A., Verhage, A., Fernández, I., García, J. M., AzcónAguilar, C., Flors, V., and Pozo, M. J. 2010. Hormonal and transcriptional profiles highlight common and differential host responses to arbuscular mycorrhizal fungi and the regulation of the oxylipin pathway. J. Exp. Bot. 61:2589-2601.

Mah, K. M., Uppalapati, S. R., Tang, Y., Allen, S., and Shuai, B. 2012. Gene expression profiling of Macrophomina phaseolina infected Medicago truncatula roots reveals a role for auxin in plant tolerance against the charcoal rot pathogen. Physiol. Mol. Plant Pathol. 79:21-30.

Manici, L. M., Caputo, F., and Cerato, C. 1995. Temperature responses of isolates of Macrophomina phaseolina from different climatic regions of sunflower production in Italy. Plant Dis. 79:834-838.

Martinez-Medina, A., Flors, V., Heil, M., Mauch-Mani, B., Pieterse, C. M., Pozo, M. J., Ton, J., van Dam, N. M., and Conrath, U. 2016. Recognizing plant defense priming. Trends Plant Sci. 21:818-822.

Mauch-Mani, B., Baccelli, I., Luna, E., and Flors, V. 2017. Defense priming: An adaptive part of induced resistance. Annu. Rev. Plant Biol. 68:485-512.

Mayek-Pérez, N., García-Espinosa, R., López-Castañeda, C., AcostaGallegos, J. A., and Simpson, J. 2002. Water relations, histopathology and growth of common bean Phaseolus vulgaris L. during pathogenesis of Macrophomina phaseolina under drought stress. Physiol. Mol. Plant Pathol. 60:185-195.

McGonigle, T. P., Miller, M. H., Evans, D. G., Fairchild, G. L., and Swan, J. A. 1990. A new method which gives an objective measure of colonization of roots by vesicular-Arbuscular mycorrhizal fungi. New Phytol. 115:495-501.

Mengistu, A., Bond, J., Nelson, R., Rupe, J., Shannon, G., Arelli, P., and Wrather, A. 2013. Identification of soybean accessions resistant to Macrophomina phaseolina by field screening and laboratory validation. Plant Health Prog. 10:1094.

Mugford, S. T., Qi, X., Bakht, S., Hill, L., Wegel, E., Hughes, R. K., Papadopoulou, K., Melton, R., Philo, M., Sainsbury, F., Lomonossoff, G. P., Roy, A. D., Goss, R. J. M., and Osbourn, A. 2009. A serine carboxypeptidase-like acyltransferase is required for synthesis of antimicrobial compounds and disease resistance in oats. Plant Cell 21: 2473-2484.

Nadeem, S. M., Ahmad, M., Zahir, Z. A., Javaid, A., and Ashraf, M. 2014. The role of mycorrhizae and plant growth promoting rhizobacteria (PGPR) in improving crop productivity under stressful environments. Biotechnol. Adv. 32:429-448.

Nivedita, Verma, P. K., and Upadhyaya, K. C. 2017. Lectin protein kinase is induced in plant roots in response to the endophytic fungus, Piriformospora indica. Plant Mol. Biol. Report. 35:323-332.

Oyewole, B. O., Olawuyi, O. J., Odebode, A. C., and Abiala, M. A. 2017. Influence of arbuscular mycorrhiza fungi (AMF) on drought tolerance and charcoal rot disease of cowpea. Biotechnol. Rep. (Amst.) 14:8-15.

Paniagua, C., Bilkova, A., Jackson, P., Dabravolski, S., Riber, W., Didi, V., Houser, J., Gigli-Bisceglia, N., Wimmerova, M., Budínská, E., Hamann, T., and Hejatko, J. 2017. Dirigent proteins in plants: Modulating cell wall metabolism during abiotic and biotic stress exposure. J. Exp. Bot. 68:3287-3301.

Pieterse, C. M., Zamioudis, C., Berendsen, R. L., Weller, D. M., Van Wees, S. C., and Bakker, P. A. 2014. Induced systemic resistance by beneficial microbes. Annu. Rev. Phytopathol. 52:347-375. 
Pivato, B., Gamalero, E., Lemanceau, P., and Berta, G. 2008. Colonization of adventitious roots of Medicago truncatula by Pseudomonas fluorescens $C 7 R 12$ as affected by arbuscular mycorrhiza. FEMS Microbiol. Lett. 289: 173-180.

Ploper, D. 2004. Economic importance and control strategies for the major soybean diseases in Argentina. Proccedings of the VII World Soybean Research Conference. Pages 606-614 in: IV International Soybean Processing and Utilization Conference. III Congreso Brasileiro de Soja. Foz do Iguasu, Brazil.

Ponce de León, I., and Montesano, M. 2013. Activation of defense mechanisms against pathogens in mosses and flowering plants. Int. J. Mol. Sci. 14:3178-3200.

Ponce De León, I., Schmelz, E. A., Gaggero, C., Castro, A., Álvarez, A., and Montesano, M. 2012. Physcomitrella patens activates reinforcement of the cell wall, programmed cell death and accumulation of evolutionary conserved defence signals, such as salicylic acid and 12-oxo-phytodienoic acid, but not jasmonic acid, upon Botrytis cinerea infection. Mol. Plant Pathol. 13:960-974.

Pozo, M. J., and Azcón-Aguilar, C. 2007. Unraveling mycorrhiza-induced resistance. Curr. Opin. Plant Biol. 10:393-398.

Pozo, M. J., Verhage, A., Jung, S. C., Lopez-Raez, J. A., and AzcónAguilar, C. 2010. Impact of arbuscular mycorrhizal symbiosis on plant response to biotic stress: the role of plant defence mechanisms. Pages 193-207 in: Arbuscular Mycorrhiza: Physiology and Function. H. Koltai, and Y. Kapulnik, eds. Springer, Dordrecht.

Pusztahelyi, T., Holb, I. J., and Pócsi, I. 2015. Secondary metabolites in fungus-plant interactions. Front. Plant Sci. 6:573.

Raaijmakers, J. M., Paulitz, T. C., Steinberg, C., Alabouvette, C., and MoënneLoccoz, Y. 2009. The rhizosphere: A playground and battlefield for soilborne pathogens and beneficial microorganisms. Plant Soil 321:341-361.

Radwan, O., Rouhana, L. V., Hartman, G. L., and Korban, S. S. 2014 Genetic mechanisms of host-pathogen interactions for charcoal rot in soybean. Plant Mol. Biol. Report. 32:617-629.

Ralph, J., Akiyama, T., Kim, H., Lu, F., Schatz, P. F., Marita, J. M., Ralph, S. A., Reddy, M. S., Chen, F., and Dixon, R. A. 2006. Effects of coumarate 3-hydroxylase down-regulation on lignin structure. J. Biol. Chem. 281:8843-8853.

Ramos, A. M., Gally, M., Szapiro, G., Itzcovich, T., Carabajal, M., and Levin, L. 2016. In vitro growth and cell wall degrading enzyme production by Argentinean isolates of Macrophomina phaseolina, the causative agent of charcoal rot in corn. Rev. Argent. Microbiol. 48:267-273.

Rech, S. S., Heidt, S., and Requena, N. 2013. A tandem Kunitz protease inhibitor (KPI106)-serine carboxypeptidase (SCP1) controls mycorrhiza establishment and arbuscule development in Medicago truncatula. Plant J. 75:711-725.

Rivero, J., Gamir, J., Aroca, R., Pozo, M. J., and Flors, V. 2015. Metabolic transition in mycorrhizal tomato roots. Front. Microbiol. 6:598.

Sanchez-Bel, P., Troncho, P., Gamir, J., Pozo, M. J., Camañes, G., Cerezo, M., and Flors, V. 2016. The nitrogen availability interferes with mycorrhiza-induced resistance against Botrytis cinerea in tomato. Front. Microbiol. 7:1598.

Santhanam, P., van Esse, H. P., Albert, I., Faino, L., Nürnberger, T., and Thomma, B. P. 2013. Evidence for functional diversification within a fungal NEP1-like protein family. Mol. Plant-Microbe Interact 26:278-286.

Schüßler, A., and Walker, C. 2010. The Glomeromycota: A species list with new families and genera. The Royal Botanic Garden Kew, Gloucester, England. http://amf-phylogeny.com/Schuessler\&Walker2010_Glomeromycota.pdf

Shi, H., Liu, Z., Zhu, L., Zhang, C., Chen, Y., Zhou, Y., Li, F., and Li, X. 2012. Overexpression of cotton (Gossypium hirsutum) dirigent1 gene enhances lignification that blocks the spread of Verticillium dahliae. Acta Biochim. Biophys. Sin. (Shanghai) 44:555-564.

Short, G. E., Wyllie, T. D., and Ammon, V. D. 1978. Quantitative enumeration of Macrophomina phaseolina in soybean tissues. Phytopathology 68:736-741.

Singh, P., Kuo, Y. C., Mishra, S., Tsai, C. H., Chien, C. C., Chen, C. W., Desclos-Theveniau, M., Chu, P.-W., Schulze, B., Chinchilla, D., Boller, T., and Zimmerli, L. 2012. The lectin receptor kinase-VI.2 is required for priming and positively regulates Arabidopsis pattern-triggered immunity. Plant Cell 24:1256-1270.
Singh, P. K., Singh, M., Agnihotri, V. K., and Vyas, D. 2013. Arbuscular mycorrhizal fungi: Biocontrol against Fusarium wilt of chickpea. Int. J. Sci. Res. Publ. 3:1-5.

Sluiter, A., Hames, B., Ruiz, R., Scarlata, C., Sluiter, J., Templeton, D., and Crocker, D. 2008. Determination of structural carbohydrates and lignin in biomass. Technical Report NREL/TP-510-42618. National Renewable Energy Laboratory, Golden, CO, U.S.A.

Smith, G. S., and Carvil, O. N. 1997. Field screening of commercial and experimental soybean cultivars for their reaction to Macrophomina phaseolina. Plant Dis. 81:363-368.

Smyth, G. K. 2005. limma: Linear Models For Microarray Data. Pages 397-420 in: Bioinformatics and Computational Biology Solutions Using R and Bioconductor. Statistics for Biology and Health. R. Gentleman, V. J. Carey, W. Huber, R. A. Irizarry, S. Dudoit, eds. Springer, New York.

Spagnoletti, F., Carmona, M., Gómez, N. E. T., Chiocchio, V., and Lavado, R. S. 2017. Arbuscular mycorrhiza reduces the negative effects of M. phaseolina on soybean plants in arsenic-contaminated soils. Appl. Soil Ecol. 121:41-47.

Spagnoletti, F. N., Balestrasse, K., Lavado, R. S., and Giacometti, R. 2016. Arbuscular mycorrhiza detoxifying response against arsenic and pathogenic fungus in soybean. Ecotoxicol. Environ. Saf. 133:47-56.

Sui, X. L., Li, A. R., Chen, Y., Zhuo, L., and Liu, Y. Y. 2014. Arbuscular mycorrhizal fungi: Potential biocontrol agents against the damaging root hemiparasite Pedicularis kansuensis? Mycorrhiza 24:187-195.

Thamil Arasan, S. K., Park, J. I., Ahmed, N. U., Jung, H. J., Hur, Y., Kang, K. K., Lim, Y. P., and Nou, I. S. 2013. Characterization and expression analysis of dirigent family genes related to stresses in Brassica. Plant Physiol. Biochem. 67:144-153.

Voets, L., de la Providencia, I. E., Fernandez, K., IJdo, M., Cranenbrouck, S., and Declerck, S. 2009. Extraradical mycelium network of arbuscular mycorrhizal fungi allows fast colonization of seedlings under in vitro conditions. Mycorrhiza 19:347-356.

Walters, D., and Heil, M. 2007. Costs and trade-offs associated with induced resistance. Physiol. Mol. Plant Pathol. 71:3-17.

Wrather, A., Shannon, G., Balardin, R., Carregal, L., Escobar, R., Gupta, G. K., Ma, Z., Morel, W., Ploper, D., and Tenuta, A. 2010. Effect of diseases on soybean yield in the top eight producing countries in 2006. Plant Health Prog. 10:1094.

Wyllie, T. D. 1988. Charcoal rot of soybeans-Current status. In: Soybean Diseases of the North Central Region. T. D. Wyllie, and D. H. Scott, eds. The American Phytopathological Society, St. Paul, MN, U.S.A.

Zamioudis, C., and Pieterse, C. M. J. 2012. Modulation of host immunity by beneficial microbes. Mol. Plant-Microbe Interact 25:139-150.

Zhu, L., Zhang, X., Tu, L., Zeng, F., Nie, Y., and Guo, X. 2007. Isolation and characterization of two novel dirigent-like genes highly induced in cotton (Gossypium barbadense and G. hirsutum) after infection by Verticillium dahliae. J. Plant Pathol. 1:41-45.

Zuluaga, A. P., Vega-Arreguín, J. C., Fei, Z., Matas, A. J., Patev, S., Fry, W. E., and Rose, J. K. 2016. Analysis of the tomato leaf transcriptome during successive hemibiotrophic stages of a compatible interaction with the oomycete pathogen Phytophthora infestans. Mol. Plant Pathol. 17: 42-54.

\section{AUTHOR-RECOMMENDED INTERNET RESOURCES}

Bolsa de Comercio de Rosario website: http://www.bcr.com.ar

Food and Agriculture Organization of the United Nations FAOstat website: http://www.fao.org

Glomeromycota In Vitro Collection (GINCO) database:

http://www.mycorrhiza.be/ginco-bel

MapMan Site of Analysis: http://mapman.gabipd.org/web/guest/home

Mycothèque de l'Université catholique de Louvain (MUCL) website: http://bccm.belspo.be/about/mucl.php

National Center for Biotechnology Information Gene Expression Omnibus (GEO) database: https://www.ncbi.nlm.nih.gov/geo/query/acc.cgi?acc= GSE87740

The R Project for Statistical Computing: https://www.r-project.org 